\title{
Amending the Foreign Corrupt Practices Act to Include a Private Right of Action
}

\author{
Daniel Pines $\dagger$
}

The Foreign Corrupt Practices Act (FCPA) forbids American businesses from bribing foreign officials. Beyond its moral implications, the FCPA can promote America's foreign policy and economic interests. Two fundamental problems with the FCPA have prevented it from serving its purposes. First, the two bodies given authority to bring suit under the FCPA, the Department of Justice and the Securities and Exchange Commission, have failed to enforce it effectively. Second, the provisions of the FCPA remain extremely vague despite amendments in 1988. In this Comment, the author argues that Congress should amend the FCPA to allow a private right of action that is restricted to competing American businesses. Such an amendment would enhance both enforcement and clarification of the FCPA. This will, in turn, allow American business to realize the FCPA's dormant benefits.

\section{INTRODUCTION}

The fall of the Soviet Union and the changes in Eastern Europe have tremendously altered American foreign policy. With the end of the Cold War, economic considerations have replaced geopolitical and military concerns. In addition, previously unreachable regions of the world are now exposed to, and in many cases are seeking, Western commercialization. These areas, however, are often rife with corruption. ${ }^{1}$ Thus, as the Clinton Administration begins to re-evaluate numerous American trade policies in

Copyright @ 1994 California Law Review, Inc.

$\dagger$ B.S.F.S. 1991, School of Foreign Service, Georgetown University; J.D. candidate 1994, Boalt Hall School of Law, University of California, Berkeley. I would like to thank the numerous individuals who helped ine fornulate and formalize this Comment. Particularly, I would like to thank Professor David Caron for aiding me in the thought process and helping me with earlier drafts. Trenendous thanks also go to James Knox and Jeff Carlisle for their editorial assistance.

1. See, e.g., Jeffrey A. Burt, Yeltsin Decree on Anti-Corruption, U.S. Law Put Investors in Difficult Dilemma, Russia \& CommonweALth Bus. L. REP., Sept. 21, 1992 (discussing widespread corruption in Russia), available in LEXIS, Nexis Library, RCBLR File; Paul Klebnikov, Joe Stalin's Heirs, Forbes, Sept. 27, 1993, at 124 (same); Frank Viviano, Dreams, Graft Mix at Borders, S.F. ChroN., Feb. 23, 1993, at A1 (discussing problems in Poland and Ukraine). 
light of the above changes, ${ }^{2}$ one policy that needs to be re-evaluated is the Foreign Corrupt Practices Act ${ }^{3}$ (hereinafter "FCPA"4 or "Act"). The FCPA forbids American businesses from bribing foreign officials. As such, it makes the United States the only nation in the world that prohibits its domestic corporations from bribing another country's public servantsalmost every country forbids the bribery of its own officials, but only the United States through the FCPA forbids the bribery of another country's officials.

Beyond any moral attributes, the Act has unrealized potential to secure significant gains for American businesses; it can spur technological development, reduce blackmail, increase support for the capitalist system, and promote both short- and long-term American economic interests. Yet, these potential gains have never been realized because of problems with the Act. The Department of Justice (DOJ) and the Securities and Exchange Commission (SEC), the only two bodies given authority to bring suit under the FCPA, have failed to enforce the Act effectively. Furthermore, the provisions of the Act remain extremely vague despite amendments in 1988 .

These problems could be solved, and the underlying benefits of the Act realized, if the FCPA allowed private citizens to bring suit under certain circumstances. However, the courts have already found that the Act does not provide for private citizens to bring suit. ${ }^{5}$ This Comment therefore urges Congress to amend the FCPA to allow a restricted private right of action. ${ }^{6}$ A restricted provision expressly allowing private suits in certain circumstances would enhance both enforcement and clarification of the FCPA. This will, in turn, allow American business to realize the Act's dormant benefits.

Part I of this Comment will describe the FCPA as enacted in 1977 and amended in 1988. Part II discusses the importance of the FCPA and explains why the current provisions of the Act limit the Act's benefits. To solve this problem, Part III urges Congress to aniend the FCPA to allow a restricted private right of action.

2. Nancy Dunne, Clinton Embarks on Broad Review of US Trade Laws-Anti-Bribery Act Under Scrutiny, Fin. TIMEs, June 10, 1993, at 6.

3. 15 U.S.C. $\$ \S 78 \mathrm{~m}(\mathrm{~b}), 78 \mathrm{dd}-1,78 \mathrm{dd}-2$, $78 \mathrm{ff}$ (1988) (originally enacted as Pub. L. No. 95-213, 91 Stat. 1494 (1977), and amended by Foreign Corrupt Practices Act Amendments of 1988, Pub. L. No. $100-418, \S \S 5001-5003,102$ Stat. 1107, 1415-25).

4. This is not to be confused with the Federal Comupt Practices Act, which is often also referred to as the FCPA.

5. Lamb v. Phillip Morris, Inc., 915 F.2d 1024, 1029 (6th Cir. 1990), cert. denied, 498 U.S. 1086 (1991).

6. The term "restricted private right of action," which I use throughout this Comment, refers to my proposed private right of action, deseribed in detail at infra Part III. I describe the private right of action as "restricted" because the right to sue will be limited to U.S. businesses which competed for a foreign contract with another U.S. business which bribed a foreign official. As such, the private right of action will not be open to individuals, foreign businesses, or noncompeting U.S. businesses. 


\section{BACKGROUND OF THE FCPA}

[The FCPA] represented Congress' determination that competition im overseas markets should be based on the merits-on price and product quality-rather than on questionable payments to foreign political leaders. Its operative principle, if I may quote Shakespeare ..., is that "corruption wins not more than honesty."

\section{-Assistant Attorney General Philip B. Heymann"}

The FCPA is one of the more interesting legacies of the Watergate conspiracy. In probing the illegal corporate contributions to the 1972 Nixon presidential campaign, the Watergate Special Prosecutor discovered numerous corporate pohtical slush funds that evaded normal accounting controls. ${ }^{8}$ To determine the extent to which such funds upset corporate accounting procedures, the SEC initiated an independent investigation of these accounts. ${ }^{9}$

The SEC investigation uncovered information indicating that several corporate slush funds had been used not only to fund pohticians in the United States, but also to make large scale bribes to foreign officials. ${ }^{10}$ In an attempt to discover how extensively U.S. corporations engaged in such actions, the SEC indicated that it would likely refrain from taking enforcement action against U.S. companies that immediately disclosed having made any such questionable payments. ${ }^{11}$

The response was surprising: over 300 firms voluntarily acknowledged having made such payments to foreign officials totaling hundreds of millions of dollars. ${ }^{12}$ The discovery that so many firms had engaged in this type of bribery was shocking to both government officials and the American public. ${ }^{13}$ The result was the unamintous passage of the FCPA, ${ }^{14}$ which President Carter signed into law on December 17, 1977.

Before the enactment of the FCPA, U.S. corporations that bribed foreign officials could only be prosecuted through indirect means. The SEC maintained that U.S. corporations were required to disclose such payments

7. Heymann Speech on the Enforcement Priorities Under FCPA, 2 Foreign Corrupt Pracs. Act Rep. (Business Laws, Inc.) 1501 (Dec. 31, 1982) [hereinafter Heymann Speech].

8. Pat Towell \& Barry M. Hager, Foreign Bribes: Stiff Penalties Proposed, 35 Cong. Q. WKLY. REP. 929, 929 (1977).

9. Id.

10. Id.

11. 4 Stanley S. Arkin et al., Business Crmie: Crmminal liabiltry of the Business CommUntTY 918.01 (1990).

12. Laura E. Longobardi, Reviewing the Situation: What Is To Be Done with the Foreign Corrupt Practices Act?, 20 VAND. J. TRANSNAT'L L. 431, 434 (1987).

13. See Harvey L. Pitt \& Karl A. Groskaufmanis, Minimizing Corporate Civil and Criminal Liability: A Second Look at Corporate Codes of Conduct, 78 GEo. L.J. 1559, 1582-84 \& n.142 (1990) (stating that "[p]ublic attention riveted on the scandal" as the number of disclosures mounted beyond the ability of the SEC to keep track).

14. JoHn T. NOONAN, JR., BRIBES 677 (1984). 
as part of the securities laws. ${ }^{15}$ In addition, prosecutors could invoke the Bank Secrecy Act, which requires the reporting of funds that are taken out of, or brought into, the United States. ${ }^{16}$ The Mail Fraud Act, which prohibits the use of U.S. mail or wire communications to transact a fraudulent commercial scheme, was also available to reach these bribes. ${ }^{17}$ However, such indirect means of preventing foreign bribery were ineffective. ${ }^{18}$ The FCPA was meant to be a more direct and effective means of enforcement.

The legislative history of the FCPA indicates that it was enacted to counter the adverse effects to foreign governments, American foreign policy, and American business when American corporations bribe foreign officials. ${ }^{19}$ President Carter noted: "[B]ribery is ethically repugnant and coinpetitively unnecessary. Corrupt practices between corporations and pubhic officials overseas undermine the integrity and stability of governinents and harm our relations with other countries. Recent revelations of widespread overseas bribery have eroded public confidence in our business institutions."20

\section{A. The Original 1977 Act}

To address these concerns, Congress created a two-pronged approach for the FCPA: disclosure and prohibition. The disclosure prong constitutes the first part of the Act and involves accounting and record-keeping provisions. This section requires a corporation to keep accurate accounts of all transactions it conducts. While this section is highly relevant for revenue proceedings, a detailed analysis of its provisions falls beyond the scope of this Comment.

The prohibition prong of the FCPA forbids the bribery of foreign officials by U.S. businesses. Specifically, the Act prohibits American companies and their agents from using the mails or other ineans of interstate commerce to inake an illicit payinent to a foreign official or politician to use his power or influence to help the American firm obtain or retain busi-

15. Paul H. Vishny, Illicit Payments and the Foreign Corrupt Practices Act of the United States, in GoIng International: INTERnational Trade fOR THE Nonspecialist 267 (A.L.l.-A.B.A. Course Study Materiais No. 395, 1990).

16. Id.

17. Id.

18. The fact that over 300 companies engaged in such transactions was discovered only through voluntary disclosure. This indicates the inability of indirect means to combat the problem. The position of the SEC, and the use of the Bank Secrecy laws, required disclosure of bribes, but did not actually forbid the use of bribery itself. Meanwhile, the Mail Fraud Act was restrictive in that it only applicd to bribes that used U.S. mail or wire communications. See NoONAN, supra note 14, at 676 . The loopholcs in these indirect methods not only prevented prosecutions, but also failed to send the desircd message that bribery of foreign officials was wrong. 4101.

19. S. Rep. No. 114, 95th Cong., 1st Sess. 3-4 (1977), reprinted in 1977 U.S.C.C.A.N. 4098,

20. Heymann Speech, supra note 7, at 1502. 
ness for itself or any other person. ${ }^{21}$ As originally enacted, if a payment were made to a third party, it was only prohibited if the firm knew or had reason to know that the payment would be used in the above corrupt manner. ${ }^{22}$ The FCPA applies to all U.S. busmesses and individuals by requiring adherence to the Act by all issuers of securities ${ }^{23}$ and all domestic concerns. $^{24}$ The FCPA also applies to any official, director, employee, agent, or stockholder acting on behalf of such issuers or doinestic concerns. ${ }^{25}$

Congress placed enforcement of the Act under the joint control of the SEC and the DOJ. The SEC had responsibility to investigate and bring civil actions for violations of the accounting provisions and for violations of the antibribery provisions that affected or involved securities issuers. ${ }^{26}$ The DOJ, meanwhile, had responsibility for investigating and bringing all criminal violations of the Act, as well as all civil violations of the antibribery provisions that did not concern securities issuers. ${ }^{27}$

\section{B. The 1988 Amendments to the Act}

From the instant the Act was implemented, American corporations complained about the Act's provisions and clamored for amendment. ${ }^{28}$ Criticism of the 1977 Act fell into two related categories. First, critics com-

2I. 15 U.S.C. $\S \S 78 d d-1(a),-2(a)$ (1977) (amended 1988). I have cited to two sections here, I(a) and 2(a), because the FCPA contains two essentially identical passages. The FCPA first describes the requirements for securities issuers against bribery. Then, it describes the exact same requirements in the exact same terms for domestic concerns, substituting the word "domestic concerns" where necessary. The separation and redundancy were created to distinguish betwecn powers under the Securities and Exchange Commission and powers under the Department of Justice. Throughout this comment, I will cite to both sections where appropriate.

22. I5 U.S.C. $\$ \S 78 d d-1(a)(3),-2(a)(3)$ (1977) (amended 1988).

23. 15 U.S.C. $\$ 78 \mathrm{c}(\mathrm{a})(8)(1977)$ (amended 1988) defines an issuer, in part, as "any person who issues or proposes to issue any security."

24. 15 U.S.C. § 78dd-2(d)(1) (1977) (current version at 15 U.S.C. § 78dd-2(h)(1) (1988)) defines "domestic concern" as:

(A) any individual who is a citizen, national, or resident of the Umited States; and

(B) any corporation, partnership, association, joint-stock company, busimess trust, unincorporated organization, or sole proprietorship which has its principal place of business in the Umited States, or which is organized under the laws of a State of the United States or a territory, possession, or commonwealth of the Umited States.

25. 15 U.S.C. $\S \S 78 d d-1$ (a), -2(a) (1977) (amended 1988). The Eckhardt Amendment forbade the prosecution of such an individual if her employing entity was not found to have violated the Act. See 15 U.S.C. $\$ \S 78 \mathrm{dd}-2(b)(3), 78 \mathrm{ff}(\mathrm{c})(3)$ (1977) (imposing liability on employees and agents "[w]henever an [issuer or domestic concern] is found to have violated" the FCPA) (amended 1988). The Eckhardt Amendment was repealed by the 1988 Amendments to the FCPA. See Executive Legal Summary No. 178: Bribery Provisions of the Foreign Corrupt Practices Act, 1 Foreign Corrupt Pracs. Act Rep. (Business Laws, Inc.) 100.08 (July 1991).

26. S. REP. No. 114, supra note 19, at 11-12, reprinted in 1977 U.S.C.C.A.N. at 4109-10.

27. Id.

28. "The ink was hardly dry before a steady drumbeat of attack on the statute began." Business Accounting and Foreign Trade Simplification Act: Joint Hearings on S. 708 Before the Subcomm. on Securities and the Subcomm. on International Finance and Monetary Policy of the Senate Comm. on Banking, Housing and Urban Affairs, 97th Cong., 1st Sess. 414 (1981) [hereinafter Business Accounting Hearings] (statement of William A. Dobrovir). 
plained that the statute's provisions were extremely vague. ${ }^{29}$ Second, they complained that the FCPA's provisions covered such a broad scope that the FCPA threatened to unduly impair the conduct of U.S. business abroad. ${ }^{30}$

In response, Congress amended the FCPA in 1988. Tied to the Omnibus Trade Bill, the new FCPA amendments made several major changes that affected the antibribery provisions of the Act. ${ }^{31}$ First, the scienter requirement for third party payments was changed from a broad "reason to know" standard to the more narrow "knowing" standard. 32 A person is deemed to "know" that a payment to a third party will be used to bribe a foreign official if the person is aware or has a firm belief that the third party is engaging in such conduct or that such a result is "substantially certain to occur."33

Second, the new amendments exempted several types of payments from FCPA prosecution. "Grease" or "facilitating" payments are excluded as long as the purpose of the payment is to "expedite or to secure the performance of a routine governmental action."34 This replaced the 1977 exemption for duties by officials that were "essentially ministerial or clerical."35 Furthermore, affirmative defenses to FCPA prosecution can be raised if the payment made was legal under the laws of the official's coun-

29. See Bartley A. Brennan, The Foreign Corrupt Practices Act Amendments of 1988: "Death" of a Law, 15 N.C. J. INT'L L. \& CoM. Reg. 229, 232 (1990); Bill Shaw, Foreign Corrupt Practices Act: Amendments of 1988, 14 MD. J. INT'L L. \& TRADE 161, 164, 166 (1990).

30. Senator Heinz noted that many sections of the antibribery provisions, especially those concerning the reason to know standard for third parties, created "assertions of breadth of coverage which themselves are breathtaking and which would totally cripple U.S. corporate activities in certain countries, were the law aggressively enforced in that way." Sen. Heinz Reintroduces Proposal to Amend Foreign Corrupt Practices Act, [Jan.-June] Sec. Reg. \& L. Rep. (BNA) No. 7, at 318 (Feb. 15, 1985).

31. Many of these new changes are analyzed in greater detail at infra notes 76-122 and accompanying text.

32. 15 U.S.C. \$\$ 78dd-1(a)(3), -2(a)(3).

33. See 15 U.S.C. $\$ \S 78 \mathrm{dd}-1(\mathrm{f})(2),-2(\mathrm{~h})(3)$ (defining "knowing" for the purposes of the FCPA in general). The subtleties and difficulties of the "knowing" standard are examined in detail at infra notes 84-105 and accompanying text.

34. 15 U.S.C. $\$ \S 78 \mathrm{dd}-1(\mathrm{~b}),-2(\mathrm{~b})$. A "routine governmental action" refers only to aetions that are "ordinarily and commonly performed by a foreign official" in:

(i) obtaiming permits, licenses, or other official documents to qualify a person to do business in a foreign country;

(ii) processing governmental papers, such as visas and work orders;

(iii) providing police protection, mail piek-up and delivery, or scheduling inspections associated with contraet performance or inspections related to transit of goods across country;

(iv) providing phone service, power and water supply, loading and unloading cargo, or protecting perishable products or commodities from deterioration; or

(v) actions of a similar nature.

15 U.S.C. $\$ \S 78 \mathrm{dd}-1(\mathrm{f})(3)(\mathrm{A}),-2(\mathrm{~h})(4)(\mathrm{A})$. The term does not include

any decision by a foreign official whether, or on what terms, to award new business to or to continue business with a particular party, or any action taken by a foreign official involved in the decision-making process to encourage a decision to award new business to or continue business with a particular party.

15 U.S.C. $\S \S 78 d d-1(\S)(3)(B),-2(h)(4)(B)$.

35. 15 U.S.C. $\S \S 78 \mathrm{dd}-1(\mathrm{~b}),-2(\mathrm{~d})(2)$ (1977) (amended 1988). 
try, ${ }^{36}$ or if the payment was a reasonable and bona fide expense, such as the costs of travel and lodging, incurred to promote or deinonstrate a product or perform a contract with a foreign government. ${ }^{37}$

Third, the amendments stipulated that the President "should" pursue international agreement among the meinbers of the Orgamization of Economic Cooperation and Development (OECD) to create FCPA-like legislation in the countries that are members of that body. ${ }^{38}$ The President was required to submit to Congress a report on these negotiations, as well as other international developments in the field. ${ }^{39}$

Fourth, after addressing the concerns of the business community, Congress raised the penalties for violating the Act. A new civil fine of up to $\$ 10,000$ was introduced as a possible sanction. ${ }^{40}$ In addition, the maximum criminal penalty for an individual was increased from $\$ 10,000$ to $\$ 100,000,{ }^{41}$ while the maximum criminal fine for a U.S. corporation was increased from $\$ 1$ million to $\$ 2$ million. ${ }^{42}$

Fifth, the amendments altered the enforcement provisions of the Act. The Attorney General was allowed to determine, after one year in whicls to acquire opinions from relevant agencies and personnel, whether a systein of guidelines or general precautionary procedures would help businesses comply with the FCPA. ${ }^{43}$ In addition, the Act essentially codified prior DOJ

36. 15 U.S.C. $\$ \S 78 \mathrm{dd}-1(c)(1),-2(c)(1)$.

37. 15 U.S.C. $\$ \S 78 \mathrm{dd}-1(c)(2),-2(c)(2)$.

38. 15 U.S.C. $\$ 78 \mathrm{dd}-1$ note.

39. Id.

40. 15 U.S.C. $\S \S 78 \mathrm{dd}-2(\mathrm{~g})(1)(\mathrm{B}), 78 \mathrm{ff}(\mathrm{c})(1)(\mathrm{B})$.

41. 15 U.S.C. $\$ \S 78 \mathrm{dd}-2(\mathrm{~g})(2)(\mathrm{A}), 78 \mathrm{ff}(\mathrm{c})(2)(\mathrm{A})$.

42. 15 U.S.C. $\S \S 78 \mathrm{dd}-2(\mathrm{~g})(1)(\mathrm{A}), 78 \mathrm{ff}(\mathrm{c})(1)(\mathrm{A})$. Violating the Act has ramifications beyond these penalties. A violation of the FCPA can serve as a "predicate act" for other criminal legislation. Amy G. Rudnick \& James M. Schwarz, Banks Must Gear Up for Comprehensive New Money Laundering Law, BANKING POL'Y REP., Dec. 21, 1992, at 1, 12 (mentioning that violations of the FCPA are predicate offenses for money laundering under the Annunzio-Wylie Anti-Money Laundering Act); see infra notes 231-40 and accompanying text (describing how the FCPA can serve as a predicate act for prosecution under the Racketeer Influenced and Comupt Organizations Act (RICO)). In addition, corporations convicted under the FCPA may be unable to obtain certain export licenses. See Arthur Aronoff, Antibribery Provisions of the Foreign Corrupt Practices Act, in The CoMmerce DePARTMENT SPEAKS 1992: DEVELOPMENTS IN IMPORT ADMINISTRATION; EXPORT AND INVESTMENT ABROAD 799, 815 (PLI Corporate Law \& Practice Course Handbook Series No. B-789, 1992) (Department of State's Office of Munitions Control can suspend or disbar persons from export licensing practice for violations of FCPA); Debarred, Suspended Firms Presumed Ineligible for Arms Export Licenses, [1988] 5 Int'1 Trade Rep. (BNA) 1526, 1526 (Nov. 23, 1988) (mentioning that persons convicted under the FCPA are automatically denied arms export licenses under the International Traffic in Arms Regulation); Donald W. Smith, Defense of Export Control Enforcement Actions, in COPING WTTH U.S. ExPORT CONTROLS 1992, at 65, 68 (PLI Commercial Law and Practice Course Handbook Series No. 607, 1992) (stating that persons merely indicted under the FCPA are usually automatically denied export privileges). Furthermore, at least 33 agencies can suspend or disbar firms that violate the FCPA antibribery provisions from procurcment or nonprocurement licensing programs. See Aronoff, supra at 812-16; see also, e.g., 17 C.F.R. § 3.20(iv)(A) (1992) (Commodities Futures Trading Commission); 22 C.F.R. pt. 709 (1993) (Overseas Private Investunent Corporation).

43. 15 U.S.C. $\S \S 78 \mathrm{dd}-1(\mathrm{~d}),-2(\mathrm{e})$. The Justice Department and the Commerce Department, at the direction of the Attomey General, issued the Foreign Corrupt Practices Act Antibribery Provisions 
procedure by requiring the DOJ to provide "opinions" regarding the legality of actions upon request by any U.S. business. ${ }^{44}$ An opinion issued by the Department that an action conforms to FCPA provisions creates a "rebuttable presumption" that such conduct is legal under the FCPA. ${ }^{45}$

II

\section{PRoBlems WTTH THE FCPA}

Despite these significant amendments, the FCPA still has numerous problems that prevent it from achieving its goals. The two main problems with the Act concern the extremely limited enforcement of the Act and the continued vagueness of many of the Act's provisions. Some critics allege that a third problem continues to plague the Act: it is economically, and even morally, harmful to U.S. business interests abroad. As will be discussed later in this section, however, the third "problem" is both exaggerated and unpersuasive.

\section{A. Enforcement}

Despite several prominent cases, ${ }^{46}$ enforcement of the FCPA's antibribery provision has been extremely limited. From 1977 to 1988 , the DOJ imitiated only twenty antibribery cases under the FCPA, and the SEC only three. ${ }^{47}$ In addition, the few cases that went to trial resulted in mini-

Brochure in February of 1992 to give "general explanations of compliance responsibilities and potential liabilities under the FCPA" as far as the DOJ is concerned. A copy of this brochure can be obtained from the DOJ and has been reprinted as an appendix to Corporate Counsel's Primer on the Foreign Corrupt Practices Act, 1 Foreign Corrupt Pracs. Act Rep. (Business Laws, Inc.) 101.01 app. C at 101.91 (Apr. 1992) [hereinafter Corporate Counsel's Primer].

44. 15 U.S.C. §§ 78dd-1(e), -2(f); see also Brennan, supra note 29, at 245.

45. 15 U.S.C. $\$ \S 78 d d-1(\mathrm{e}),-2(\mathrm{f})$.

46. Major firms that pleaded guilty to violations of the antibribery provisions of the FCPA include International Harvester, see Notice of Plea Agreement and Plea Agreement, United States v. International Harvester Co. (S.D. Tex. 1982) (No. 82-244), reprinted in 2 Foreign Corrupt Pracs. Act Rep. (Business Laws, Inc.) 696.31, 696.31 (Jan. 31, 1984), Goodyear Intcrnational, see Notice of Plca Agreement and Plea Agreement, United States v. Goodyear Int'l Corp. (D.D.C. 1989) (No. 89-0156), reprinted in 2 Foreign Comupt Pracs. Act Rep. (Business Laws, Inc.) 698.17, 698.17 (July 1989), and Young \& Rubicam, see Plea Agreement, Umited States v. Young \& Rubicam, Inc. (D. Conn. 1990) (No. N-89-68(PCD)), reprinted in 2 Foreign Corrupt Pracs. Act Rep. (Business Laws, Inc.) 698.51, 698.5101 (July 1990). In addition, Ashland Oil consented to be permanently enjoined from violating the FCPA, but did not admit guilt. Final Order as to Ashland Oil, Inc., SEC v. Ashland Oil, Inc. (D.D.C. 1986) (No. 86-1904), reprinted in 2 Foreign Comupt Pracs. Act Rep. (Business Laws, Inc.) 697.06, 697.06-.07 (Oct. 1, 1986).

47. Sherry R. Sontag, Bribery A Close Call: Is New Legislation Really Needed?, Nar'L L.J., May 9, 1988, at 1, 16. As of 1991, only two dozen U.S. corporations had been convicted of violating these provisions. Jim Doyle, Judge Tosses Out Overseas Bribery Case, S.F. Chron., Mar. 20, 1991, at B6; see also Executive Legal Summary No. 5: The Revised Foreign Corrupt Practices Act, 1 Forcign Corrupt Pracs. Act Rep. (Business Laws, Inc.) 100.01, 100.03 (Oct. 1988) (asserting that "only a few cases" had been brought by the DOJ, involving "rather flagrant violations"); Thomas W. Hill, Jr., Foreign Representatives: Saudi Law and the FCPA, 1 Foreign Corrupt Pracs. Act Rep. (Business Laws, Inc.) 200.0101, 200.0115 (Apr. 1989) ("Criminal prosecutions [under the FCPA] have been rare."). 
mal penalties, usually consisting only of an injunction to prohibit the corporation from violating the FCPA in the future. ${ }^{48}$

Numerous factors are responsible for the Act's minimal enforceinent. One factor is the ineffectiveness of the agencies charged with inaintaining the FCPA provisions. From the beginning, the DOJ was not given complete control over enforcement of the Act because Congress believed that the DOJ was not effective in rooting out white collar crime. As Senator William Proxmire, Chairman of the Senate Committee on Banking, Housing and Urban Affairs, asserted: "If we learned anything in the Watergate affair, we learned that the Department of Justice is not a departinent we can always rely on, especially when you have top influential corporate officials that are involved." 49 The SEC, meanwhile, was not given complete control of enforcement because of the difficulty of overcoming the DOJ's unchallenged inonopoly on federal criminal prosecution, as well as concerns regarding the propriety of "an administrative agency which is adjudicative, rulemaking, and investigative" also bringing criminal prosecutions. $^{50}$ The minimal enforcement brought by these two agencies underscores the legislative concerns regarding their effectiveness.

Compounding the DOJ's and SEC's individual inefficiencies is their inability to cooperate effectively on FCPA matters. The original concept behind mutual enforcement was to have the SEC initiate investigations, closely cooperate with the Justice Department at the earliest stage of investigation, allow the SEC to bring injunctive relief for violations of securities law, and have the DOJ bring criminal sanctions. ${ }^{51}$

Unfortunately, this cozy interplay between the agencies has never occurred. While the accounting and antibribery provisions tend to overlap in many cases, joint efforts by the DOJ and SEC to investigate and prosecute are virtually nonexistent. ${ }^{52}$ Additionally, while the DOJ implemented a Review Program ${ }^{53}$ in which it provides advice that creates a presumption of legality in proceedings brought by the DOJ, the SEC officially refuses to accept these DOJ decisions as binding on SEC investigations. ${ }^{54}$ Finally, plea agreements signed by parties tend not to exclude actions by the other

48. A survey of the FCPA litigation from December 1982 to January 1992 reported in the Foreign Corrupt Practices Act Reporter reveals this to be the case. See 2 Foreign Corrupt Pracs. Act Rep. (Business Laws, Inc.) 635-99.005.

49. Foreign and Corporate Bribes: Hearings on S. 3133 Before the Senate Comm. on Banking, Housing and Urban Affairs, 94th Cong., 2d Sess. 15 (1976). S. 3133 was a precursor to the FCPA.

50. Id. at 22 (statements of Sen. William Proxmire and Ralph Nader).

51. See S. REP. No. 114, supra note 19, at 11-12, reprinted in 1977 U.S.C.C.A.N. at 4109-10.

52. Litigation reported by the Foreign Corrupt Practices Act Reporter froin April 1978 to January 1992 does not show that the DOJ and SEC have ever worked together in an FCPA prosecution. See 2 Foreign Corrupt Pracs. Act Rep. (Business Laws, Inc.) 609-99.005.

53. See supra notes $44-45$ and accompanying text.

54. The SEC has, however, informally stated that it will abide by DOJ opinions and refrain from prosecuting companies that obtain approval under the Review Program. See Corporate Counsel's Primer, supra note 43, at 101.06. 
agency. ${ }^{55}$ Thus, if a corporation signs a plea agreement with the DOJ, the plea agreement will not exclude the potential for future action by the SEC.

In addition to these problems, enforcement is also hobbled by the difficulties inherent in prosecuting FCPA cases. As the Senate realized in 1977, "there may be practical impediments to enforcement in individual cases, just as proof of bribery and other white collar crimes is often difficult to obtain in domestic cases." 56 In actuality, the Senate's concerns were probably understated-acquiring proof of foreign bribery is a more difficult task than obtaining evidence for a domestic case, since a foreign government official necessarily is involved. Not only may a foreign government shield this official's actions, but the United States has no direct means to subpoena her or conduct discovery. Furthermore, such cases require not only cooperation from foreign nationals, but also cooperation from branches of the U.S. government concerned with both foreign policy and defense that might have conflicting interests with the DOJ and the SEC. ${ }^{57}$ Finally, the distance, the culture, and the players involved can interfere with foreign investigations. 58

An interview with a former federal prosecutor provides a concrete example of the problems associated with FCPA prosecutions. ${ }^{59} \mathrm{~A}$ recent investigation involved alleged bribes paid by the Olin Corporation to South African officials to facilitate an arms sale to that country. A federal prosecutor claimed that, in addition to discovery problems, the prosecutors had "the sense that, for whatever reason, our government would not go to the mat with the South African government to allow us to interview South

55. This has, in any case, not been shown by any plea agreements reported by the Foreign Corrupt Practices Act Reporter from December 1982 to January 1992. See 2 Foreign Corrupt Pracs. Act Rep. (Business Laws, Inc.) 609-99.005.

56. S. REP. No. 114, supra note 19, at 12, reprinted in 1977 U.S.C.C.A.N. at 4110.

57. Lyn Bixby, Arms Experts Grounded in the Dirty Deal, HARTFord Courant, Oct. 27, 1992, at A1; see also Longobardi, supra note 12 , at $489-90$ (mentioming that DOJ may refrain from notifying the Department of State of an investigation for some time in order to avoid politicization and maintain secrecy). There have becn numerous occasions on which the State Department attempted to convince the SEC or DOJ to restrict its investigations, especially when the SEC or DOJ was considering whether to reveal the names of countries or officials under investigation. Kate Gillespie, Middle East Response to the U.S. Foreign Corrupt Practices Act, 29 CAL. MGMT. Rev. 9, 10 (1987). An informal procedure, in fact, was created between the DOJ and the State Department to deal with concerns about the foreign policy implications of FCPA investigations. Id. at 10-11; see also Lawrence W. Newman \& Michael Burrows, Private Claims Under the Foreign Corrupt Practices Act, N.Y. L.J., Feb. 20, 1992, at 3 ("[T] Jus Justice Department and the SEC coordinate enforcement of the FCPA with the State Department."). Foreign policy concerns of other government organizations or the Executive Branch generally can thus limit FCPA enforcement by the DOJ and SEC. See Margaret A. Niles, Note, Judicial Balancing of Foreign Policy Considerations: Comity and Errors Under the Act of State Doctrine, 35 StAN. L. REv. 327, 359 (1983).

58. See Longobardi, supra note 12 , at $476-77$ (detailing burdens of investigation and prosecution involving foreign venues).

59. Bixby, supra note 57 , at A1. 
African nationals." ${ }^{" 60}$ Olin eventually pleaded no contest to lesser charges. ${ }^{61}$

Thus, the deficiencies of the DOJ and SEC, the inherent difficulties in prosecuting foreign bribery cases, and a possible lack of political support for certain prosecutions has led to minimal enforcement of the FCPA. ${ }^{62}$ This minimal enforcement has had three unfortunate consequences. First, it is unlikely that the FCPA has effectively eliminated the bribery of foreign officials. ${ }^{63}$ Second, limited enforcement signals a lack of U.S. resolve on this issue. Foreign nations would be more likely to enact legislation similar to the FCPA if the Act were shown to be effective. American unwillingness to enforce the FCPA's provisions provides no impetus for foreign countries to adopt sucl1 moral legislation. Third, the lack of enforcement has served to limit a major means by which FCPA provisions could become clearer. Courts are often the forum where the subtleties of legislation can be clarified. ${ }^{64}$ Without prosecution, however, judges are unable to perform this vital task. ${ }^{65}$

\section{B. Vagueness}

Despite amendments in 1988, the FCPA is still plagued with problems of vagueness that hinder its intended purpose. ${ }^{66}$ Without clearly defined terms and requirements, the FCPA proves ineffective in providing guidance for U.S. corporations. Minimal enforcement of the Act's provisions has contributed to this ineffectiveness by reducing agency incentive, as well as court ability, to clarify the FCPA's terms.

Several negative consequences result from such confusion. Some firms, afraid of violating the terms of the FCPA, withdraw from contracts in

60. Id. (statement of $\mathrm{H}$. James Pickerstein).

61. Id.

62. It is also possible that few cases have been prosecuted beeause corporations may settle these disputes before they become public. Laws with evil-sounding names such as the Foreign Corrupt Practices Act create fear amongst corporations of the bad publicity attendant to their violation: "To avoid bad press and accusations of unpatriotic behavior, companies promptly settle disputes arising under these and other trade regulations." Note, Predictability and Comity: Toward Common Principles of Extraterritorial Jurisdiction, 98 HARv. L. REv. 1310, 1316 n.33 (1985).

63. However, at least two commentators argue that the FCPA has, at least to some extent, limited bribery of foreign officials. See George H. Mazzarantani, Foreign Corrupt Practices Act, 26 AM. CRMM. L. Rev. 855, 872 (1989); On the Take, Economist, Nov. 19, 1988, at 21, 22.

64. Of course, if the courts interpret wording in a manner adverse to legislative intent or desire, Congress is able, and often chooses, to pass legislation to clarify its desires. Without court action, though, Congress may not have the impetus.

65. The fact that "[t]he Department of Justice has instituted a number of cases under the Foreign Corrupt Practices Act, but none conceming the bribery provisions has been fully litigated at trial," Corporate Counsel's Primer, supra note 43, at 101.20, mdicates that limited enforcement of the Act is depriving the courts of the chanee to define many crucial issues.

66. For detailed hypotheticals exemplifying this vagueness in the bribery prong of the FCPA, as well as discussion of the ramifications of such vagueness, see id. at 101.34.43. 
which "questionable" payments may have been at issue, ${ }^{67}$ while others might agree to contracts that they wrongly believe conform with the Act. Even worse, there is a strong likelihood that numerous other firms may engage in rather obvious bribery arrangements, believing that the vagueness means that the chances of being caught, prosecuted, and severely punished are slight. ${ }^{68}$ Such consequences resulting from the FCPA's vagueness are detrimental to both American business and the objectives of the FCPA.

Greater court action could rectify some of the gray areas in the Act. Already, the courts have clarified several hazy portions of the FCPA. The Supreme Court has held that the Act of State doctrine will not bar consideration of cases involving bribery of foreign officials. ${ }^{69}$ It may thus be inferred that the act of state will not bar prosecution under the FCPA. Other federal courts lave also interpreted the FCPA in various ways: foreign officials cannot be prosecuted for conspiracy to violate the FCPA $;{ }^{70}$ only bribes that are made for the express reason of promoting business practices are forbidden; ${ }^{71}$ the FCPA does not apply to violations that occurred prior to the Act's creation in $1977 ; 7^{72}$ and executors of an estate cannot recover bribes paid to foreign officials. ${ }^{73}$

In the end, however, the courts have not had an opportunity to define most of the key factors. The extremely limited number of cases brought before the courts ${ }^{74}$ restricts their ability to define pertinent aspects of the FCPA. Moreover, the fact that such cases tend to involve blatant violations

67. See John E. Impert, A Program for Compliance with the Foreign Corrupt Practices Act and Foreign Law Restrictions on the Use of Sales Agents, 24 INT'L LAw. 1009, 1011 (1990); Ford S. Worthy, When Somebody Wants a Payoff, Fortune, Fall 1989 (Special lssue: Pacific Rim), at 117.

68. There is no explicit support for this assertion since firms are unlikely to step forward and claim that they are violating U.S. law. There is, however, evidence that American firms may bc becoming complacent about enforcement. See, e.g., Arthur T. Downey, No Time for Complacency on Corporate Corruption, Conn. L. TRIB., July 1, 1991, at 24.

69. W.S. Kirkpatrick \& Co. v. Environmental Tectonics Corp., Int'l, 493 U.S. 400, 409-10 (1990).

70. See United States v. Castle, 925 F.2d 831, 856 (5th Cir. 1991) (holding that Canadian officials could not be prosecuted for receiving a bribe from a U.S. company under conspiracy to violate the FCPA).

71. As articulated in 15 U.S.C. $\$ \S 78 \mathrm{dd}-1(\mathrm{a}),-2(\mathrm{a})$, the FCPA is concerned only with bribes that are made for business purposes. The courts have defined the "business purpose" test narrowly, and have refused to allow FCPA prosecution in cases on the periphery. For example, a district court in Miami recently determined that a bribe made to offieials of the Dominican Republie to acquire the release of a plane allegedly involved in drug smuggling was not within the "business purpose" test of the FCPA. Judge Dismisses Charges Against Prominent Democrat, UPI, Apr. 17, 1990, available in LEX1S, Nexis Library, UPI File.

72. Northrop Corp. v. Triad Fin. Establishment, 593 F. Supp. 928, 940-41 (C.D. Cal. 1984) (holding that the wording and legislative history of the FCPA did not support its retroactive application, and that such retroactive application would, in any case, "face serious constitutional barriers"), rev' $d$ on other grounds sub nom. Northrop Corp. v. Triad Int'l Mktg., S.A., 811 F.2d 1265 (9th Cir.), cert. denied, 484 U.S. 914 (1987).

73. Sedco Int'1, S.A. v. Cory, 522 F. Supp. 254, 321 (S.D. Iowa 1981) (bribe paid to an Arab state official to secure concession held unrecoverable), affd, 683 F.2d 1201 (8th Cir.), cert, denied, 459 U.S. 1017 (1982).

74. See supra note 47 and accompanying text. 
of the Act indicates that judges have few opportunities to establish precedent regarding the niore ambiguous provisions of the Act. ${ }^{75}$

The provisions of the FCPA that are deenied overly vague can best be analyzed by breaking the requirements for FCPA prosecution into its several coniponents. In order for the DOJ or the SEC to prosecute a U.S. corporation for violating the FCPA antibribery provisions, the agency must show that the firm took the following steps: ${ }^{76}$

(1) a company, officer, or eniployee

(2) used the mails or another means or instrumentality of interstate commerce

(3) corruptly

(4) to pay, offer, or promise to pay soniething of value (the "payinent")

(5) to a foreign official, political party, or candidate for political office (i.e., directly) or to any person, while knowing that part of such payment will be given to a foreign official, political party, or candidate for political office (i.e., through a third party)

(6) for the purposes of influencing an act or decision of the foreign official

(7) in his/her official capacity

(8) in order to obtain or retain business

(9) unless:

(a) such act is a routine governmental action;

(b) the payinent was lawful under the written laws and regulations of the foreign official's nation; or

(c) the paynient was for a reasonable and bona fide expenditure, sucli as travel and lodging, related to the promotion or demonstration of services or the performance of a contract.

The following discussion utilizes the above chart to examine the difficulties associated with understanding the antibribery provisions of the FCPA and to illustrate the confusion that U.S. firms experience as the result of such uncertainty.

\section{When Has a Corporation Acted "Corruptly"? (Step 3)}

The FCPA prohibits corporations from using the mails "corruptly" in furtherance of payments to foreign officials. ${ }^{77}$ The term corrupt has been defined as "counot[img] an evil motive or purpose, an intent to wrongfully influence the recipient."78 However, just what constitutes an "evil" intent is susceptible to varying interpretations. Thus, some commentators have

75. See supra note 47 .

76. Terms in italics are those considered particularly vague and addressed specifically at infra Part II.B.1-5.

77. 15 U.S.C. $\S \S 78 \mathrm{dd}-1$ (a), $-2(\mathrm{a})$.

78. S. REP. No. 114, supra note 19, at 10, reprinted in 1977 U.S.C.C.A.N. at 4108. 
questioned whether a corporation can have an evil intent if it is following the practices and customs, although perhaps not the express written laws, of a foreign country. ${ }^{79}$

\section{What Constitutes Making a "Payment"? (Step 4)}

The FCPA applies when the user employs the mails or interstate commerce "in furtherance of an offer, payment, promise to pay, or authorization of the payment of any money, or offer, gift, promise to give, or authorization of the giving of anything of value" to a foreign official. ${ }^{80}$ The ambiguity lies in how far a defendant must go to consummate the making of a payment to an official before violating the FCPA. The legislative history failed to stipulate whether a very preliminary act (e.g., depositing money into a bank to use as payment) suffices to violate the FCPA. Instead, it only states that there is no requirement "that the act [of payment] be fully consummated, or succeed in producing the desired outcome." 81 The courts and the relevant agencies have not provided further guidance, ${ }^{82}$ and commentators are divided on the issue. ${ }^{83}$

\section{What Is Meant by the "Knowing" Standard? (Step 5)}

The "knowing" requirement, established in the 1988 amendments to clarify the requisite scienter for third party payments, is the provision that has caused the greatest amount of confusion among commentators and corporations. ${ }^{84}$ The "knowing" requirement remains extremely vague, despite extensive discussion in both the statute and the committee report. The fact that neither the DOJ nor the SEC has yet prosecuted an FCPA violation where the corporation's knowledge of the payment was at issue ${ }^{85}$ makes it much more difficult to determine the exact parameters of the "knowing" standard. ${ }^{86}$

79. See, e.g., 4 ARKIN ET AL., supra note 11, I 18.04, at 18-17 to 18-18.

80. 15 U.S.C. $\$ \S 78 d d-1(a),-2(a)$.

81. S. REP. No. 114, supra note 19, at 10, reprinted in 1977 U.S.C.C.A.N. at 4108.

82. See Corporate Counsel's Primer, supra note 43, at 101.14-.25 (showing that cases and DOJ opinions from 1980 to 1989 did not address the definition of "payment").

83. Although the most common reading holds that there needs to be at least an actual offer or promise of payment for the Act to be triggered, some have suggested that even a preliminary act such as a bank deposit can suffice. See, e.g., 4 ARKiN ET AL., supra note 11, I 18.04, at 18-19.

84. See, e.g., Burt, supra note 1 (arguing sarcastically that the new standard was "[s]ome clarification indeed!").

85. See Corporate Counsel's Primer, supra note 43, at 101.09-.25 (showing that DOJ and SEC enforcement actions from 1980 to 1989 did not raise the question of knowledge).

86. When Congress amended the FCPA in 1988, it replaced the heavily problematic "reason to know" standard with a "knowing" requirement. Many commentators have questioned whether the new "knowing" standard really changes the mens rea requirement from the old "reason to know" standard. See, e.g., Dale C. Turza, Corrupt Practices Act: How Far Have We Come?, N.Y. L.J., Apr. 5, 1990, at 5,6 (arguing that the change is unlikely to "forge a meaningful difference in the niens rea requirement for a violation"); see also More on "Know" Standard, Export Control News, Nov. 26, 1991 (comparing the standard of knowledge used in regulations concerning chemical and biological weapon proliferation with that used in the FCPA, and stating "[t]here is no basis for concluding that the court 
In both the amendments and conference reports of 1988, Congress attempted to provide some detail as to what constituted "knowing."87 However, such detail has proven inadequate. As one commentator notes:

It would appear that the only circumstance from which a company must now protect itself is the intentional disregarding of some mix of subjective and objective signals that illegal payments were made by an agent or employee to a third party. It is not clear at this point what the signals are. ${ }^{88}$

Thus, for example, nowhere in the legislative discussion of the "knowing" standard is there any suggestion of liability "where the consequences of the factual knowledge possessed by the defendant may result in future conduct

would apply a 'reason to know' standard . . . differently than a 'know' standard"), available in LEXIS, World Library, ZWLD2 File. If, in fact, the standard does not effectively narrow the scienter requirement, then the numerous problems expressed by firms concerning the 1977 "reason to know" requirement are still legitimate. For a discussion of the vagueness of the "reason to know" requirement, see Hill, supra note 47, at 200.0121-.0124, and Brennan, supra note 29, at 237-38. Brennan also mentions that there were no precedents interpreting the "reason to know" language of the 1977 FCPA, id. at 238, and that a 1981 GAO Report fonnd that almost $50 \%$ of the respondents surveyed described the "reason to know" language to be "very inadequate" or "marginally madequate," id. at 237 (citing U.S. Gen. Accountang Office, Report to the Congress: Impact of Foreign Corrupt Practices ACT ON U.S. BusINESS 60 (1981) [hereinafter GAO REPORT]).

87. The 1988 Amendments defined the new standard as follows:

(A) A person's state of mind is "knowing" with respect to conduct, a circumstance, or a result if-

(i) such person is aware that such person is engaging in such conduct, that such circumstance exists, or that such result is substantially certain to occur; or

(ii) such person has a firm belief that such circumstance exists or that such result is substantially certain to occur.

(B) When knowledge of the existence of a particular circumstance is required for an offense, such knowledge is establisled if a person is aware of a high probability of the existence of such circumstance, unless the person actually believes that such circumstance does not exist. 15 U.S.C. $\S \S 78 \mathrm{dd}-1(\mathrm{f})(2),-2(\mathrm{~h})(3)$. The Conference Report of 1988 provides some guidance on this standard:

[T]he Conferees agreed that "simple ncgligence" or "mere foolishness" should not be the basis for liability. However, the Conferees also agreed that the so-called "head-in-the-sand" problem-variously described . . . as "conscious disregard," "willful blindness," or "deliberate ignorance"-should be covered so that management officials could not take refuge from the Act's prohibitions by their unwarranted obliviousness to any action (or inaction), language or other "signaling device" that should reasonably alert thein of the "high probability" of an FCPA violation.

H.R. REP. No. 576, 100th Cong., 2d Sess. 920 (1988), reprinted in 1988 U.S.C.C.A.N. 1949, 1953. The Conference Report analyzed how federal case law has attempted to ascertain the "knowing" standard for other acts. From this analysis, the rcport asserts that "[ $t]$ he knowledge requirement is not equivalent to 'recklessness.' It requircs an awareness of a high probability of the existence of the circumstance." Id. As authority for this proposition, the Report quoted the following passage from United States v. Jacobs, 475 F.2d 270, 287 n.37 (2d Cir.), cert. denied sub nom. Lavelle v. United States, 414 U.S. 821 (1973):

[I]f you find that a defendant acted with reckless disregard of whether the bills were stolen and with a conscious purpose to avoid learning the truth the requirement of knowledge would be satisfied, unless the defendant actually believed they were not stolen.

....

- You should scrutinize the entire conduct of the defendant at or near the time the offenses are alleged to have been committed.

H.R. REP. No. 576, supra at 920, reprinted in 1988 U.S.C.C.A.N. at 1953.

88. Brennan, supra note 29 , at 239. 
prohibited by the statute." 89 Yet the language contained in the statute creates liability if the U.S. corporation had the awareness or belief that "such result is substantially certain to occur." 90

Arthur Aronoff provides an example of the inherent probleins of such a vague standard:

A U.S. firm negotiating an export transaction with an export intermediary is told that the intermediary's commission (which was to be very high, although within a range seen by other U.S. firms in the lost country) is to be paid in part to the intermediary and part to the U.S. bank account of the XYZ Corporation. When the exporter asked about the reason for these arrangements, it was told that it was none of its business.

Slould a U.S. firm continue with its export transaction under these circumstances? ${ }^{91}$

Aronoff never provides an answer to the question. Because no cases explain what "knowing" (or other commonly used buzzwords such as "conscious disregard" or "deliberate ignorance") means within the context of the FCPA, "it is unclear whether and to what extent there is a duty of diligent inquiry into any suspicious details concerming arrangements with an intermediary."92 Nonetheless, Aronoff suggests that the exporter should engage in sucli an inquiry before proceeding with the transaction. ${ }^{93}$

Other commentators have also suggested that a U.S. corporation should engage in due diligence investigations whenever it uses an intermediary to enter a foreign inarket. ${ }^{94}$ However, such investigations can prove problematic. The investigations can be extremely difficult, since they must cover a range of factors that can indicate the potential for an FCPA violation. ${ }^{95}$ Moreover, the requirements for fulfilling a due diligence standard are undefined and ambiguous. ${ }^{96}$ It is thus difficult to know how much

89. Hill, supra note 47 , at 200.0127 (emphasis added).

90. 15 U.S.C. $\$ \S 78 \mathrm{dd}-1(\mathrm{f})(2)(\mathrm{A})(\mathrm{i}),-2(\mathrm{~h})(3)(\mathrm{A})(\mathrm{i})$.

91. Arthur Aronoff, Complying with the Foreign Corrupt Practices Act; Legal Aspects of Exporting and Investing, Bus. AM., Feb. 11, 1991, at 10.

92. Id. The language of the Act also seems to imply that U.S. corporations may be prosecuted if they sell their goods to a foreign distributor who, in turn, engages in transactions that would violate the FCPA, so long as the U.S. corporation "knew" of the affair. See E. Grey Lewis \& Donald J. Kissinger, Reconstruction Contracting: Avoiding FCPA Pitfalls, MiddLE EAsT EXECUTIVE Rep., Aug. 1991, at 16.

93. Aronoff, supra note 91 , at 10.

94. See Impert, supra note 67 , at 1014.

95. See Executive Legal Summary No. 778 , supra note 25, at 100.05-.06 (suggesting twelve points to check for compliance evaluation); see also Impert, supra note 67, at 1018 (setting forth "red flags" to look for when retaiming an agent).

96. For an analysis of some of the problems that can arise under a "due diligence" standard, see Pamela H. Bucy, Corporate Ethos: A Standard for Imposing Corporate Criminal Liability, 75 Minv. L. Rev. 1095, 1162-64 (1991). For a more detailed assessment of the problems associated with using the due diligence standard in the context of FCPA investigations, see Hill, supra note 47, at 200.0126.0128 . 
investigation is necessary, or to figure out what degree of awareness that a bribe might be made constitutes "knowing" that a bribe might be made.

The problems related to the "knowing" standard become exacerbated when U.S. corporations work with local nationals in arranging contracts. Firms utilize foreign agents not only because the cost of maintaining a U.S. expatriate employee in the foreign country for an extended period may be extremely costly, ${ }^{97}$ but also because a foreign agent typically knows how the local system works and often has contacts with numerous important government officials.

However, such agents pose numerous problems for FCPA compliance. The foreign sales agent is "steeped in another culture . . . where illicit payments may be prevalent."98 Furthermore, the U.S. corporation can often only supervise the agent's actions from afar, smce one reason for employing the agent is to avoid administrative costs in the foreign country. Lastly, since such sales agents are usually paid on a contingency fee basis, ${ }^{99}$ the agents have an incentive to use any means available to acquire the contract. All of these factors can lead to the use of bribery by a foreign sales agent, resulting in FCPA prosecution of the U.S. primcipal. As a precaution against such agent-initiated bribery, or at least against prosecution under the FCPA if the agent does bribe, commentators can only suggest that prior to hiring a foreign agent, a firm should conduct an extensive background investigation of the foreign agent. ${ }^{100}$

A related area of concern is the utilization of joint ventures, whereby U.S. corporations teain up with local corporations. ${ }^{101}$ In many countries, foreign investors are required, or at least strongly encouraged, to grant wide operational authority to local partners when they create joint ventures. ${ }^{102}$ As with the local agent, the local enterprise, having a lot of power and little supervision, may engage in bribery. The problem intensifies when, as

97. Impert, supra note 67 , at 1013 .

98. Id. at 1023 .

99. Id. at 1013.

100. See, e.g., Robert J. Eck, Getting Started, in Global Intellectual Property Series 1992: Practical Strategies-Trademark and Copyright 11 (PLI Patent, Copyright, Trademark, and Literary Property Course Handbook Series No. 341, 1992); Impert, supra note 67, at 1018.

101. Virtually all the FCPA problems associated with joint ventures arise when U.S. corporations create subsidiaries out of foreign corporations or groups of foreign nationals. Although foreign subsidiaries are not directly covered by the FCPA, the parent company can be directly subject to the FCPA if it is considered to have participated in the making of a corrupt payment. 3B HAROLD S. Bloomenthal, Securities and Federal Corporate Law § 11.26[3], at 11-157 (Clark Boardman Callaghan Sec. Law Series, 1993).

102. See, e.g., Brian L. Zimbler, Soviet Foreign Investment Laws and Practices, 1987-1990: A Practitioner's Perspective, 4 Transnat'L Law. 85, 107-11 (1991) (describing joint ventures in the Soviet Union); Ford S. Worthy, Keys to Japanese Success in Asia, ForTuNE, Oct. 7, 1991, at 157 (describing practices in Pacific Rin countries). 
sometimes happens, the local enterprise is affiliated with a highly placed or well-connected government official. ${ }^{103}$

The confusion arising from the knowledge standard of the FCPA has greatly affected the manner in which U.S. corporations engage in joint ventures and, consequently, their competitiveness abroad. In order to "know" what a foreign partner does, U.S. corporations often feel compelled to control the venture, which means owning a majority stake. ${ }^{104}$ Not only may such requirements be offensive to the foreign partner, but they tend to restrict the investment opportunities of U.S. corporations. Japanese investors, by contrast, do not feel compelled to acquire majority shares; they are more willing to accept whatever ownership terms are required in order to solidify the deal. This flexibility allows the Japanese investor greater opportunities and helps explain "how Japan's winners are outselling the West." 105

\section{When Is an Official Engaged in an "Official Capacity"? (Step 7)}

The FCPA requires that the foreign official ${ }^{106}$ be engaged in an "official capacity" or "lawful duty" when the alleged illegal conduct occurs. ${ }^{107}$ It often proves difficult, however, to distinguish between conduct of a foreign official in that person's "official" capacity and conduct in her personal or business capacity. As one commentator mentions: "Given the endemic absence of administrative and substantive law in the countries where these issues arise, proof of a given foreign official's 'legal duty' can be expected to pose rather interesting problems and issues."108

There are other related problems with the official capacity requirement. In nations where the government fully or partially controls businesses, the issue of whether the managers of such businesses are government officials remains unclear. Similarly, in many nations, such as Russia, it is difficult to determine exactly which persons employed by the government are truly "officials."109

103. For examples of where this has proven extremely controversial and confusing in Russia, see Burt, supra note 1 .

104. Worthy, supra note 102, at 158. John Wong, former head of IBM's Singapore operations and the current group managing director of Singapore's Hong Leong Corp., a trading and manufacturing firm, claims that with "[e]very proposal that comes across my desk, the Western company will say it has to have $55 \%$ of the deal." Id.

105. Id. at 157.

106. "The term 'foreign official' means any officer or employee of a foreign government or any department, agency, or instrumentality thereof, or any person acting in an official capacity for or on behalf of any such government or department, agency, or instrumentality." 15 U.S.C. $\$ 78 d d-I(f)(1)$, 2(h)(2).

107. 15 U.S.C. §§ 78dd-1(a)(1)(A), -2(a)(1)(A).

108. Hill, supra note 47 , at 200.0119 .

109. See Burt, supra note 1. 


\section{What Constitutes a "Routine Governmental Action"? (Step 9(a))}

The FCPA allows payments for a "routine governmental action,"110 ineaning actions that are "ordinarily and commonly performed by a governinent official," 11 and provides a safe harbor hist of actions considered as such. However, payinents made to affect a foreign official's decision to award new business or retain old business are still prohibited. ${ }^{112}$

As might be expected, there are numerous problems with the "routine governinental action" exception. First, it is often difficult to determine whether payinents are made for "routine governmental actions." As one commentator notes: "The 'routine actions' exemption helps, but it doesn't tell you whether you can safely buy dinner for the minister, or whether you can buy a snack in the cafeteria after a working session but not dinner at a French restaurant."113 Exacerbating the situation is the fact that payments for government actions abroad are often conducted on a scale that, though common in the foreign country and between the parties concerned, would seem excessive to American officials enforcing the FCPA. ${ }^{114}$ Linked to this problem is the issue of whether the aniount spent is even relevant, an issue not discussed by the FCPA. ${ }^{115}$ Further confusing the issue is the fact that the FCPA's list of safe harbor actions considered "routine governmental actions" includes "actions of a similar nature"116 to those specifically listed. This is patently vague, opeming the door to further confusion.

\section{Can the DOJ Review Procedure Answer These Questions?}

One theoretical solution to these problems is for U.S. corporations to utilize the DOJ review procedure. ${ }^{117}$ The fact that this procedure has been rarely used, however, indicates that it is only marginally effective in clarifying ambiguous standards like the "knowing" standard. ${ }^{118}$ Firms prefer not to draw attention to their transactions by announcing them to the DOJ. While this inay be because the firm believes its actions occupy a gray area of FCPA regulation, there may be other, less sinister, reasons. For example, firms may believe that the thirty-day turn-around for a review ${ }^{119}$ is too

110. 15 U.S.C. $\S \S 78 \mathrm{dd}-1(\mathrm{~b}),-2(\mathrm{~b})$.

111. 15 U.S.C. $\$ \S 78 \mathrm{dd}-1(\mathrm{f})(3)(\mathrm{A}),-2(\mathrm{~h})(4)(\mathrm{A})$; see also supra note 34 (quoting statute).

112. 15 U.S.C. $\S \S 78 \mathrm{dd}-1(\mathrm{f})(3)(\mathrm{B}),-2(\mathrm{~h})(4)(\mathrm{B})$.

113. William E. Holland, Gift Rapping, WASH. Post, Sept. 8, 1991, at E3.

114. Hill, supra note 47 , at 200.0120 .

115. See Holland, supra note 113 , at E3 (mentioning that the 1988 amendments rejected a proposed exception for "nominal" gifts).

116. 15 U.S.C. $\$ \S 78 \mathrm{dd}-1(\mathrm{f})(3)(\mathrm{A})(\mathrm{v}),-2(\mathrm{~h})(4)(\mathrm{A})(\mathrm{v})$.

117. See supra notes $44-45$ and acconipanying text.

118. See Lewis \& Kissinger, supra note 92, at 16. From 1980 to its codification in 1988 , only 19 firms submitted proposals to the review procedure. Executive Legal Summary No. 5, supra note 47, at 100.04 .

119. 15 U.S.C. $\S \S 78 \mathrm{dd}-1(e),-2(f)$. 
slow. ${ }^{120}$ In addition, firms may not want to inform competitors of their plans or cast aspersions upon the business ethics of their foreign clients. Most importantly, they may not want their actions associated in any way with the FCPA and its negative impact on the corporate image. ${ }^{121}$

Aside from the hesitancy of firms to use the procedure, the procedure as designed is unlikely to produce consistent and reliable results. The DOJ review procedure confines itself to the specific acts alleged ${ }^{122}$ and does not create precedent or general guidance. Thus, for example, it is unlikely that the procedure will elucidate general standards by which firms can be considered "knowing." In short, the DOJ review procedure is not an adequate option for firms interested in clarifying for themselves the meanings of any of the above terms.

\section{Alleged Problems with the Concept of the FCPA}

Aside from the vagueness and enforcement problems identified above, various critics of the FCPA take issue with the very existence of the Act. They identify two quite different criticisms of the Act: (1) the FCPA is an offensive display of moral imperialism; and (2) the FCPA is unacceptably damaging to American economic interests abroad.

However, neither of these claims proves very meritorious when examined in depth. The claim of moral imperialism tends to evaporate when the underlying concepts are more thoroughly analyzed. Meanwhile, the economic argument, while valid to some extent, is both exaggerated and short-sighted. The argument disregards the short-term economic benefits of the Act, overlooks the FCPA's long-term (and in fact more significant) economic benefits, and completely fails to consider the moral and geopolitical benefits for the United States that stem from the FCPA.

\section{The Moral Imperialism Argument Is Unpersuasive}

Some critics allege that the FCPA is a shameful form of cultural imperialism, whereby the United States attempts to impose its moral beliefs on foreign nations whose cultures contemplate a different means of conducting business. ${ }^{123}$ As one commentator notes, citing to the FCPA as an example,

120. As Senator D'Amaţo stated in 1981 about business transactions in general, "[w]e must recognize that, in the heat of international nuarkets, our businessmen cannot afford to await the advice of armies of lawyers, accountants and consultants before taking any action." Business Accounting Hearings, supra note 28, at 2 . This is even nore important in today's world where faxes, modems, and portable computers make business transactions even quicker.

121. See supra note 62.

122. See 15 U.S.C. $\S \S 78 \mathrm{dd}-1(\mathrm{e}),-2(\mathrm{f})$ ("The opinion shall state whether certain specified prospective conduct would . . . violate [the FCPA antibribery provisions].").

123. See The Activities of American Multinational Corporations Abroad: Hearings Before the Subcomm. on International Economic Policy of the House Comm. on International Relations, 94th Cong., 1st Sess. 24 (1975) [hereinafter Activities of American MNCs Abroad Hearings] ("It would be not only presuniptuous but couuterproduetive to seek to inipose our specific standards in countries with differing histories and cultures. Moreover, enforeement of such legislation . . . would be widely 
"We do not hesitate, either as individual Americans or as a government, to indulge in cultural ignorance, which the rest of the world perceives as cultural arrogance." 124 Revelations of bribery may not only create einbarrassinent for the exposed officials, but also for the foreign nation involved. ${ }^{125}$ Payments of bribes by U.S. corporations to foreign officials, and the subsequent exposure of such payments, played a part in the fall of governments in Japan, ${ }^{126}$ Bolivia, ${ }^{127}$ Honduras, ${ }^{128}$ the Cook Islands, ${ }^{129}$ Italy, ${ }^{130}$ and the Netherlands. ${ }^{131}$

Despite these dramatic consequences of bribery, the claim that the FCPA itself constitutes a form of cultural imperialisin is flawed. No commentator on the FCPA has yet pointed to a nation that has legislation that expressly condones the bribery of government officials. Thus, though commentators tend to be overly careful in making this point, ${ }^{132}$ it appears that every nation in the world already forbids bribery of government officials. As such, it is difficult to contend that the FCPA is imperialistically imposing its ideals in the rest of the world. ${ }^{133}$

resented abroad.") (statement of Mark B. Feldman, Deputy Legal Adviser to the State Department); Geoffrey Gamble \& Theodore F. Killheffer, The Enemies of United States' Trade Competitiveness: A Lawyer's Perspective, Del. LAw., Winter 1988, at 12 (1988); U.S. Trade Trips Hint at Needed Change, On \& GAS J., Jan. 20, 1992, at 17, 17; see also Hill, supra note 47, at 200.0101-.0102.

124. Gamble \& Killheffer, supra note 123 , at 12.

125. However, the Supreme Court has refused to allow such embarrassment of foreign nations to preclude prosecution under the FCPA. W.S. Kirkpatrick \& Co. v. Environmental Tectonics Corp., Int'l, 493 U.S. 400, 409-10 (1990) (determining that bribes are not considered acts of a foreign sovereign and hence are not within the act of state doctrine).

126. John C. Coffee, Jr., Beyond the Shut-Eyed Sentry: Toward a Theoretical View of Corporate Misconduct and an Effective Legal Response, 63 VA. L. REv. 1099, 1103 n.7 (1977).

127. Id.

128. Id.

129. Offer of Proof, United States v. Kenny Int'l Corp. (D.D.C. 1979), reprinted in 2 Foreign Comupt Pracs. Act Rep. (Business Laws, Inc) 649, 650 (Dec. 31, 1982).

130. Longobardi, supra note 12 , at 433 .

131. Id.

132. Bruce Zagaris of Berliner \& Maloney stated at an American Bar Association annual meeting that "corruption of government officials today is expressly prohibited in virtually all countries," though such laws "are fraught with vagne provisions and uneven enforcement." Lawyers Warned of Growing Criminal Exposure in International Business, [1989] 6 Int'l Trade Rep. (BNA) 1100 (Aug. 23, 1989).

133. In fact, if any nation is found expressly to allow bribery of its government officials, or changes its laws to so allow, the FCPA, by its very terms, will no longer apply to transactions occurring within that nation. The 1988 Amendments created an affirmative defense for any actions where "the payment, gift, offer, or promise of anything of value that was made, was lawful under the written laws and regnlations of the foreign official's, political party's, party official's or candidate's country." 15 U.S.C. $\S \S 78 \mathrm{dd}-1(\mathrm{c})(1),-2(\mathrm{c})(1)$. It can even be argued that these provisions would apply to nations that, while not expressly allowing bribery, at least do not expressly prohibit it. This is especially true when one considers that legislation tends to be proscriptive (i.e., whatever is not exprcssly forbidden is allowed) and thus a failure to forbid bribery of government officials would indicate the lawfulness of such an activity. Contra 4 ARKIN ET AL., supra note 11, I 18.05, at 18-32 to 18-33. Regardless of whether the defense applics, the FCPA accounting provisions would still require that the U.S. corporation disclose the bribe on its financial statements. See id. 
Instead, the "FCPA does no more than echo a unanimous international legal and moral principle: bribery is bad." 134 As Judge John T. Noonan, who wrote one of the defimitive works on bribery, asserts:

There are some laws such as those on ganibling that are constantly broken without any particular sense of shame attaching to the offense. Bribery law is not among them. In no country do bribetakers speak publicly of their bribes, or bribegivers announce the bribes they pay. No newspaper lists them. No one advertises that he can arrange a bribe. No one is honored precisely because he is a big briber or a big bribee. ${ }^{135}$

In the unlikely case of a nation where bribery is illegal, but is nevertheless truly considered an acceptable part of life, exposure under the FCPA would not constitute "moral imperialism" since the populace would, presumably, not find such actions by its officials to be immoral.

In any case, the moral imperialism argument is overzealous. For the most part, suits brought under the FCPA have had no major impact on the foreign nations involved. ${ }^{136}$ For example, in the Middle East, a region renowned for its alleged corruption, the "host-country response to most cases [brought under the FCPA] was minimal with no immediate or clear destabilizing effect to the Middle Eastern regime involved."137 Furthermore, far from being damaging to the nation involved, such revelations are sometimes met with varying degrees of support. As the Attorney General of Botswana explained:

Certainly no self-respecting African country would consider U.S. legislation aimed at curbing corrupt practices of American transnational enterprises in their foreign host states to be "presumptuous" or in any way "an interference." On the contrary, most Third World nations would appreciate such legislation. You see, developing countries have difficulties in discovering offenses committed by U.S. corporations in so far as their bribing and corrupting of local government officials. ${ }^{138}$

Congress noted that "[g]iven world-wide outcry against the corrupting influence of some United States-based multinationals on foreign governments, the Committee believes that most countries would welcome a greater

134. Business Accounting Hearings, supra note 28, at 414 (statement of William A. Dobrovir).

135. NoONAN, supra note 14 , at 702 .

136. While numerous foreign governments have fallen due to bribery of foreign officials by U.S. businesses, none of these governments fell due to FCPA suits. Of the six governments to have fallen in recent times due to bribery by U.S. corporations, see supra text accompanying notes 126-31, only the Cook Islands' government has fallen since the enaetment of the FCPA. In that case, the actions of the judicial system of the Cook Islands, which occurred before any FCPA suit was brought in the United States, led to the downfall of the government. See infra note 195.

137. Gillespie, supra note 57 , at 12.

138. S. ReP. No. 1031, 94th Cong., 2d Sess. 4-5 (1976) (statement of Chairman William Proxmirc, quoting the Attomey General of Botswana). 
effort by the United States to discourage offensive.conduct by U.S. companies, wherever their activities nuay take place."139 While such statements are certainly propagandistic and tainted with political overtones, ${ }^{140}$ there is evidence that, in fact, sonre cases brought under the FCPA pronipted cleanups in the foreign nations implicated. ${ }^{141}$ These cleanups indicate that the foreign nations mvolved did not simply dismiss or disdain the revelation of bribery, but felt compelled to solve the problent.

\section{The Economic Harm Argument Is Unpersuasive}

Beyond the inoral imperialism argument, critics of the FCPA complain that the Act poses an economic threat to American international business. ${ }^{142}$ They assert that, as a result of the Act, U.S. corporations often have a hard time closing deals ${ }^{143}$ and are unable to entertain prospective clients as lavishly as other foreign corporations. ${ }^{144}$ The position of these critics draws strength from the oft-repeated assertion that, despite the fact that virtually every nation in the world has officially outlawed the bribery of government officials, ${ }^{145}$ many countries rarely enforce such laws and con-

139. Id. at 4 .

140. Since exposure of corruption could lead to the overthrow of governments, it is unlikely that most national governments would objectively desire to have their corruption exposed. See, e.g., Isabel Hilton, The Whistle-Blower, THE INDEPENDENT (London), Aug. 29, 1993, at 2 (discussing the Mexican government's refusal to accept allegations that its officials were corrupt).

141. Gillespie, supra note 57, at 24-25.

142. See, e.g., Bixby, supra note 57, at A1; Bill Mintz, Ban on Bribery Hinders U.S. Companies Abroad, Hous. Chron., Jan. 15, 1992, Business Section, at 1; U.S. Trade in the Gulf Down; Call to End Restrictive Tax Laws, Middle EAst News Network, May 19, 1990, available in LEXIS, Nexis Library, OMNI File; Worthy, supra note 67, at 117-18; see also Michael A. Mayo, Ethical Problems Encountered by U.S. Small Businesses in International Marketing, J. SMALL Bus. MGMT., Apr. 1991, at 51 (inferring from survey results that marketers may elect to avoid foreign markets rather than risk prosecution under the FCPA). Others have described the situation in more emphatic terms:

When you introduce a concept like the Foreign Corrupt Practices Act you have to ask yourself what does it do to the exports. And let me tell you, there are countries in the world where you won't sell products, you just can't sell it. It's hard to believe, but that's how it works. Do you have any idea what it is like in Saudi Arabia? I lived there, and I'm telling you, aside from the personal danger, you don't sell anything unless there is someone getting it one way or the other. And you're not going to change the morality in Saudi Arabia. ... What the hell are you going to do about the legislation? It is the stupidest [expletive deleted] law I've seen in my life.

Oliver A. Houck, With Charity for All, 93 YALE L.J. 1415, 1509-10 (1984) (alteration in original) (quoting Transcript of Telephone Conversation Between John Richard, NYPIRG, and Dan M. Burt, President of Capital Legal Foundations 5 (Apr. 11, 1984) (unpublished manuscript, on file with Oliver A. Houck)).

143. "Because of the [FCPA], U.S. companies are at a disadvantage. I've never seen it happen, but sometimes clients kecp you away from certain situations. Americans do have a hard time closing deals here. . . . Other foreign uationals are much freer." Duncan Robinson, Russia: Payoffs Endanger Emergence of Market, Inter Press Service, July 27, 1992, available in LEXIS, Nexis Library, OMNI File.

144. Worthy, supra note 67 , at 118 .

145. See supra note 132 . 
sider bribery of officials a typical and acceptable mode of economic life. ${ }^{146}$ Consequently, many corporate representatives claim that "they have no choice but to go along with the system of payoffs in order to compete with European and Japanese firms." 147

These claims, however, are unpersuasive for several reasons. First, no clear evidence links the FCPA with economic harm to U.S. businesses. Second, the critics' short-term analysis of economic harm to U.S. business neglects to consider both the short- and long-term economic benefits of the Act. Finally, the focus on economic loss overlooks the various noneconomic benefits possible under the FCPA.

\section{a. The FCPA Has Had No Evident Negative Economic Impact on U.S. Business Abroad}

While some businesses complain about the harmful effects of the FCPA on American business abroad, no study confirms the validity of these claims. The only surveys which support the complaints are polls of the business community's perceptions of the Act's negative effects. More objective studies reveal that the FCPA has had no perceptible effect on U.S. international business.

Critics of the Act typically cite surveys which suggest that the FCPA has injured American business overseas. In a 1981 General Accounting Office (GAO) survey of 250 of the top 1000 corporations in the United States, about $30 \%$ of the respondents claimed that the Act had caused a decrease in business. ${ }^{148}$ Similarly, a Louis Harris poll conducted in 1983 revealed that $78 \%$ of the respondents believed that the Act makes it difficult to conduct business in countries where bribery is a form of life. ${ }^{149}$

These surveys, however, are not determinative of whether the FCPA actually affected U.S. businesses. For example, a closer examination of the GAO study reveals that the results were not quite as dire as critics of the FCPA would like to purport. The $30 \%$ figure, representing the percentage

146. See, e.g., John Barham, Menem's Clean Image Burns as Argentina Fiddles, Fin. Times, Apr. 3, 1991, at 3 (Argentina); Bixby, supra note 57, at A1 (Iran); Coping with Corruption: The Darker Side of Trading with China, Bus. Crmna, Mar. 25, 1991; Louise Lief \& Douglas Pasternak, The Spoils of Victory, U.S. News \& WORzD Rep., Mar. 2, 1992, at 44, $44-47$ (Kuwait); id. at 46 (Africa); Mintz, supra note 142 (Middle East); Robinson, supra note 143 (Russia); Worthy, supra note 67, at 117 (East Asia).

147. Protecting the Ability of the United States to Trade Abroad: Hearing on S. Res. 265 Before the Subcomm. on International Trade of the Senate Comm. on Finance, 94th Cong., 1st Sess. 7 (1975) (statement of Sen. Frank Church). The United States is the only nation to prohibit its corporations from bribing foreign officials. Studies of European corporations have found that $90 \%$ of European companies simply follow the local business practice of the nation in which they invest or to which they export, even if such practices violate the moral standards of their home nations. Joel Bainerman, Ethics and Business, Jerusalem Post, Apr. 8, 1991, at A7 (discussing a survey conducted by Dr. Meir Tamari, economist at the Bank of Israel).

148. GAO REPORT, supra note 86 , at 59.

149. The Antibribery Act Splits Executives, Bus. Wk., Sept. 19, 1983, at 16; see also Ellen F. Paul, Business Abroad, in Commerce AND Moralrty 180, 184 (Tibor R. Machan ed., 1988). 
of respondents who believe that the Act led to a decrease in American business, includes the almost $20 \%$ of respondents who found that the Act had effectuated only "[s]omewhat of a decrease in business" as opposed to a "moderate" or "great decrease in business." 150 Furthermore, 67\% of those surveyed reported that the Act had little or no effect on business. ${ }^{151}$

Even inore problematic is the fact that these types of surveys only allowed for broad responses to rather vague questions. For example, the GAO Survey asked, "In your opinion, to what extent, if at all, has the Foreign Corrupt Practices Act affected your total overseas business?" Though the respondents were provided several multiple choice answers, ranging from a "great increase in busmess" to a "great decrease in business," they were not allowed to give an explanation for their responses. ${ }^{152}$ The Louis Harris poll was even more simplistic insofar as it merely elicited a yes or no answer to the question of whether American compames had lost business due to the Act. ${ }^{153}$ While allowing business executives considerable leeway in responding, the answers were necessarily subjective. An international firm would much rather attribute its decline in business (or even unfulfilled expectations of growth) to corrupt practices by the competition than to the firm's own poor planning or even market fluctuations beyond its control. ${ }^{154}$ Consequently, the survey results probably exaggerate the actual impact of the FCPA.

Soon after the publication of the GAO study, one commentator correctly noted that the claim that U.S. companies have lost exports because of the FCPA "is often made and never substantiated. There is mucli evidence against it."155 One part of this counterevidence comes from a survey conducted by John Graham and Mark McKean which reveals that the FCPA did not hinder American exports to foreign nations from 1977 to $1984 .{ }^{156}$ In fact, despite the alleged restrictiveness of the FCPA, America's portion of exports to "corrupt" countries, where bribery is considered endennic, grew as fast as its portion of exports to "non-corrupt" countries. ${ }^{157}$

Another study focused on the effect of the FCPA on the Middle East, an area which "attained a certain notoriety" as being endemically cor-

150. GAO REPORT, supra note 86 , at 59 .

151. Id.

152. Id.

153. The Antibribery Act Splits Executives, supra note 149, at 16.

154. John C. Burton, Business Forum: A Guarantee for Long-Term Trouble, N.Y. TMEs, Mar. 20, 1983 , at C2.

155. Business Accounting Hearings, supra note 28, at 414 (statement of William A. Dobrovir).

156. See On the Take, supra note 63 , at 21 .

157. Id. This result may have stemmed from the fact that the DOJ and the SEC rarely enforce the FCPA. See supra text accompanying notes 46-65. Lack of enforcenent, however, hardly nullifies Graham and McKean's findings. Busimesses complaim that they are currently losing business due to the FCPA and that harsher measures will induce greater suffering. The Graham and McKean study questions whether businesses have really suffered and, thus, leaves open the question of whether greater enforcement or harsher sanctions in the future will adversely affect American businesses. 
rupt. ${ }^{158}$ This study indicates that, even in that part of the world, "[t]he FCPA potential to hurt U.S. exports remains unproved."159 While U.S. export share has dropped in that region of the world, ${ }^{160}$ the decline cannot be blamed on the FCPA since a large portion of the decline is directly attributable to other factors such as increased competition in the Middle East market from foreign corporations and the revolution in Iran, which alone accounted for almost half of the drop in U.S. market share in the region. ${ }^{161}$ Thus, even in one of the most "corrupt" areas of the world, it is unclear that the FCPA has caused any loss to U.S. business.

\section{b. Critics Overlook the Short-Term and Long-Term Economic Benefits of the FCPA}

Lost in the rhetoric advanced by opponents of the FCPA are the numerous short-term economic benefits of the FCPA. First, the FCPA prevents American firms from becoming involved in extortionate relationships. Once companies start to make bribes to foreign officials, it is almost impossible for them to extract themselves. As one commentator notes: "Once you let a single corrupt official, working under the aegis of 'custom,' rearrange your business ethics for you, you are wed to moral submissiveness as long as you do business in his country." 162 Not only does the current official expect a bribe for every contract in the future, but so too do her successors as well as others im the government. Moreover, if the business then fails to provide such a bribe, it can be blackmailed. ${ }^{163}$ A change in government is unlikely to solve the problem, since subsequent administrations are not only likely to demand the sanie treatment, but may in fact up the ante. ${ }^{164}$

American businesses can elude such continuous blackmail by complying with the FCPA from the beginning. ${ }^{165}$ Business personalities acknowledge this benefit of the FCPA. Ed Kilburn, chief compliance officer for ITT, notes that "it has been helpful to most American businessmen to be able to say, 'No, I can't do that. It's against U.S. law.'"166 Jeffrey M.

158. Gillespie, supra note 57 , at 9.

159. Id. at 28. The study focused on the repercussions of the FCPA on the Middle East during the years from 1975-1982, when the U.S. share of market imports to the region fell from $17.0 \%$ to $10.3 \%$. Id. at 20 . The U.S. share had already dropped to $14.6 \%$ by the time the FCPA was enacted in 1977 . Id. Clearly, there is a need for more recent studies of the impact of the FCPA. John Graham is expected to release such an updated study in the near future.

160. Id. at 20 .

161. Id.

162. Tad Tuleja, Beyond the Bottom Lne 152 (1985).

163. Id.

164. Thomas Griffith, Payment is Not Accepted Practice, in Contemporary Moral Controversies in Business 451, 453 (A. Pablo Iannone ed., 1989).

165. See Corruption: Getting Tough Pays Off, Bus. CHINA, Jan. 11, 1993 (describing how U.S. firms in China have avoided blackmail through use of the FCPA).

166. Worthy, supra note 67 , at 118. 
Kaplan, a partner in the U.S. firm of Chadbourne and Parke, concurs: "Most corporations, frankly, are happy to have an excuse not to become entangled with shady practices overseas."167

One firm's recent experience in China provides a succinct illustration of this benefit. Colgate-Palmolive was able to fend off demands for bribery from Chinese officials by pointing to the FCPA every time officials asked for bribes. ${ }^{168}$ The result: Colgate-Palmolive opened a $\$ 20$ million factory in Guangdong in January of 1992 without resorting to bribery. ${ }^{169}$ ColgatePalmolive also used this technique to avoid numerous requests for future bribes, nepotistic employment, and payment for the issuance of the factory's business license. ${ }^{170}$ An observer of the Palmolive-Colgate deal warns American businesses that "[o]nce a hidden cost is accepted, it will re-occur. Every payment is a precedent for the next. A reputation for high ethical standards can stave off a lot of demands."171 Thus, the FCPA allows U.S. corporations to avoid extra charges and future blackmail, while at the same time adhering to high ethical standards.

Perhaps equally beneficial is the FCPA's impact on corporate codes of conduct. One commentator noted that "[t]he most common provisions [of corporate codes] can be traced to the impetus for many of these codes-the FCPA."172 As of 1987, a survey of American companies by Fried, Frank indicated that $94.7 \%$ of the respondents adopted a written code of conduct or ethics and, of these, $83.3 \%$ specifically discussed the FCPA. ${ }^{173}$ These codes, in large part prompted by the FCPA, now address conflicts of interest, political contributions, antitrust, labor relations, and insider trading. ${ }^{174}$ As such, they aid U.S. corporations in regulating employer conduct and therefore help the corporation avoid future sanctions and lawsuits that could prove costly.

Furtherinore, the FCPA helps decrease the cost of doing business abroad, since bribery can prove exceedingly expensive, but yield no results. It is often difficult to know whom to bribe or how much to pay. ${ }^{175}$ Bribes often include payments made through intermediaries to unknown "connected" parties. In fact, payments may not be passed on to the connected

167. When in Rome, MNCs Don't Always Do as the Romans, Bus. INr'L, July 16, 1990. This desire to provide guidance for U.S. corporations has been described as an inherent aspect of the FCPA, an attempt by Congress to relieve "the pressure to succumb to the lowest common denominator of corporate behavior." Activities of American MNCs Abroad Hearings, supra note 123, at 62 (statement of Phillip A. Loomis, Jr., Commissioner of the SEC) (quoting Raymond Garrett, Speech Before the American Society of Corporate Secretaries (June 27, 1975)).

168. Corruption: Getting Tough Pays Off, supra note 165.

169. Id.

170. Id.

171. Id.

172. Pitt \& Groskaufmanis, supra note 13,1603 n.264. Examples of such codes can be found in 2 Foreign Corrupt Pracs. Act Rep. (Business Laws, Inc.) 1511-72.

173. Pitt \& Groskaufmanis, supra note 13 , at $1602-03$ nn.257 \& 261.

174. Id. at 1603 n.261.

175. On the Take, supra note 63 , at 21 . 
party, or the connected party may not even exist. Finally, even if the payment is sufficient and goes to the right person, that person may not award the contract to the bribing corporation, possibly because another corporation has provided an even greater bribe! Needless to say, it is very difficult for firms to get their money back, ${ }^{176}$ and the IRS will not allow the firm to deduct the payment as a busmess expense. ${ }^{177}$ The FCPA thus confers a short-term benefit to the extent that it allows firms to avoid these additional costs of doing busmess.

Not only can firms realize the above short-term benefits, but the FCPA also has the potential to yield significant long term benefits because it increases the long-term competitiveness of U.S. firms. Unable to rely on the use of bribes, American corporations will be forced to turn to alternative means to acquire contracts, such as the production of better products using superior technology. American corporations will thus hold a significant advantage over their European and Asian rivals due to these advances. Such an advantage will become even more pronounced if nations worldwide initiate actions to eradicate bribery. American firms, having already adapted to non-bribery modes of conducting business, will be well ahead of their European rivals.

Various antibribery programs in several countries suggest that bribery may be diminishing in the near future, indicating that non-bribery methods of conducting business will, in fact, be of considerable benefit to U.S. corporations. Operation Clean Hands, an effort by five judicial prosecutors to rid Italy of corruption, has already led to over 800 arrests and is perhaps the most obvious example of this trend. ${ }^{178}$ No less impressive are the recent developments in South Korea, where President Kim Young Sam's desire to eliminate corruption has placed more than 1000 people in jail since Kim took office in February 1993. ${ }^{179}$ Japan, led by its new Prime Minister Morihiro Hosokawa, pledged that ehmination of "contributions" to public officials is a key element of the electoral reforms that are the "No. 1 priority of [his] administration."180 In Guatemala, President Ramiro de Leon Carpio initiated drastic measures to eradicate corruption, including a

176. See, e.g., Sedco Int'l, S.A. v. Cory, 522 F. Supp. 254, 321 (S.D. Iowa 1981) (bribe paid by decedent to a state official of Qatar to secure concession unrecoverable by estate), aff'd, 683 F.2d 1201 (8th Cir.), cert. denied, 459 U.S. 1017 (1982).

177. Aronoff, supra note 42 , at 816.

178. See John Moody, Sick of It All, Time, Mar. 8, 1993, at 48.

179. South Koreans Arrest 4 Former Officials on Bribery Charges, N.Y. TimEs, July 18, 1993, at A11.

180. David E. Sanger, Japan Prime Minister Offers Political Reform Plan, N.Y. Times, Sept. 18, 1993, at A2; see also David E. Sanger, A Crusader for Change: Morihiro Hosokawa, N.Y. TIMES, July 30, 1993, at A1; James Sterngold, After Struggle, Reformer is Chosen as Japan's Premier, N.Y. TimEs, Aug. 7, 1993, at A3; James Sterngold, Japan's Leader Vows Action on Political System, N.Y. Times, Aug. 24, 1993, at A8. 
request that the entire Congress resign. ${ }^{181}$ Many other nations, such as Argentina ${ }^{182}$ and Romania, ${ }^{183}$ are also initiating procedures to eliminate corruption in their countries.

The United States currently has leverage to force other countries to adopt anticorruption policies at home and abroad. The former Soviet Bloc countries currently look to Western nations, especially the United States, for financial support. The United States can imduce nations to clean up their internal corruption by making aid dependent on such cleanup. Even if the U.S. government chooses not to initiate such a policy, a strong FCPA can cause such cleanups. If American corporations are stringently prohibited froin bribing foreign officials, American corporations will be unable to enter markets where corruption prevails. Nations desiring American business will be induced to crack down on corruption in order to acquire such American business. Currently, the most obvious nation where foreign trade is inducing an anticorruption canipaign is Mexico, which has undergone changes to secure the U.S. passage of the North American Free Trade Agreement (NAFTA). ${ }^{184}$ There are indications that other nations have also moved to reduce corruption in their nations for the specific purpose of encouraging American investment. ${ }^{185}$

In addition to discrete short-term and long-term economic benefits, the FCPA also serves to strengthen the free market system in general. Bribery sabotages the free nuarket system at the core of capitalism; the best product at the best price does not win. ${ }^{186}$ When the best product is not purchased because of bribery, "there is an mplication that the desired decision could not have been gained through open competition." 187 This damages the

181. Tim Golden, Guatemala Chief, Fighting Corruption, Demands Congress Quit, N.Y. TIMES, Sept. 1, 1993, at A6; Tim Golden, No Purge Yet in Guatemala, but a Battle Royal, N.Y. TIMES, Sept. 8, 1993, at A11.

182. See Barham, supra note 146 , at 3; Downey, supra note 68 , at 24 .

183. Romania Tackling Corruption Charges, E. EUR. ENERGY REP., June 10, 1993, available in LEXIS, World Library, ZEURI File.

184. See Marjorie Miller, Mexico Officials Blame Ex-Police in 2 Kidnapings, L.A. TIMEs, June 14, 1992, at A10; Yukon to Yukatan, THE Tmes (London), Aug. 13, 1992, at A11.

185. See Downey, supra note 68, at 24; see also Michael D. McNickle, Group Set to Combat Third-World Graft, INT'L HERALD TRIB., Oct. 2, 1993 (mentioning interest of several countries im Transparency International, an organization established to provide countries with technical expertise to combat comuption). It has become abundantly clear that Western corporations are more content to invest in uncorrupt nations than in corrupt ones. See Michael Richardson, U.S. to Seek Anti-Bribery Treaty, INT'L HERALD TRIB., July 28, 1993 (stating that western investment is attracted to the relatively uncorrupt nation of Singapore); Philip Shenon, Missing Out on a Glittering Market, N.Y. TIMES, Sept. 12, 1993, at $\mathrm{Cl}$ (noting that corruption is one factor keeping U.S. firms from investing in Malaysia); Morning Edition (NPR radio broadcast, May 13, 1992) (mentioning that Lebanon's leader needs to reduce corruption to attract western investment), available in LEXIS, Nexis Library, NPR File.

186. See Tuleja, supra note 162, at 156 . Bribery is problematic because it is essentially a sellout to the rich. NoONAN, supra note 14, at 703. If decisions are inade solely on the basis of monetary payment, the deepest pocket will prevail. Id.

187. Jack N. Behrman, Essays on Ethics in Business and the Professions 290 (1988). 
entire free competition concept of capitalism. ${ }^{188}$ Even if the best product is purchased, bribery undermines the capitalist system by creating an added expense to the market system. ${ }^{189}$

\section{The FCPA Provides Important Moral and Geopolitical Benefits}

Perhaps even more important than the often-overlooked economic benefits of the FCPA are the noneconomic benefits derived from the Act. The most evident noneconomic benefit of the Act is simply that it upholds a valued moral standard. The House Report on the FCPA provides an apt summary of the Act's moral element:

The payment of bribes to influence the acts or decisions of foreign officials, foreign pohtical parties or candidates for foreign political office is unethical. It is counter to the moral expectations and values of the American public .... [I]t rewards corruption instead of efficiency and puts pressure on ethical enterprises to lower their standards or risk losing business. ${ }^{190}$

Beyond the moral element, the FCPA greatly aids U.S. geopolitical interests. To begin with, bribery can have serious ramifications for the foreign nations involved. Bribery by American corporations has led to the downfall of numerous foreign governments, including allies of the United States. ${ }^{191}$ These incidents demonstrated the unwelcome influence that American corporations can have in foreign countries ${ }^{192}$ and showed how revelations of bribery can seriously damage U.S. interests in those countries. ${ }^{193}$

Even if the revelation of bribes do not cause the government to fall, American corporations' illegal payments can still have serious foreign policy implications. A $\$ 3$ million payment by Gulf Oil to the controlling political party in South Korea has been widely considered, even by Gulf's president Bob Dorsey, to have been the deciding factor in the 1971 election

188. "The ethic [the United States] must support to survive is the ethic of the free market and it is essential to the free market that govemments enforce honest competition." The Basics of Bribery, WALL St. J., Feb. 27, 1976, at 8, reprinted in Selected Readinos on International Payoffs 30, 31 (Yerachmiel Kugel \& Gladys W. Gruenberg eds., 1977); see also When in Rome, MNCs Don't Always Do as the Romans, supra note 167.

189. See The Basics of Bribery, supra note 188 , at 30 .

190. H.R. ReP. No. 640, 95th Cong., 1st Sess. $4-5$ (1977). In an editorial in The Wall Street Joumal, one commentator summarized the moral predicament of bribcry by stating, "To argue that Americans should tolerate-because it might be in their own interests-the victimization of the people of Japan or Italy is to apply a dangerous double standard. It is dangerous because the higher of two standards almost always sinks to the level of the lower one." The Basics of Bribery, supra note 188, at 31.

191. See supra text accompanying notes 126-31.

192. "What other multinational could match the Lockheed record of having implicated in improprieties the heads of state of four nations (Italy, Turkey, Japan, and the Netherlands)?" TULEjA, supra note 162, at 153 .

193. H.R. REP. No. 640 , supra note 190 , at 5 . 
in that nation. ${ }^{194}$ Similarly, payments by Kenny International, a U.S. corporation, to the ruling political party in the Cook Islands assisted that party's successful re-election (and downfall when the bribes were revealed) im 1978. ${ }^{195}$ Events suclı as these undermine American foreign policy-foreign policy should be made by the American government, not by American multinational corporations abroad.

The question, then, is how to effectuate change to make the FCPA less ambiguous, more effective, and inore productive of the benefits mentioned above. So long as the FCPA is minimally enforced and inadequately detailed, the United States will fail to monitor its own businesses, fail to send the correct inessage abroad, and fail to induce foreign nations to alter their policies. These failures could create short-term losses for American businesses and prevent American businesses from being in a position where they can realize the long-term advantages that can be reaped when other nations act against corruption or enact legislation like the FCPA. To remedy these problenis, the enforcement and vagueness problems of the FCPA need to be solved.

Normally, inadequacies in laws are reniedied through actions by government agencies, the courts, Congress, or private citizens. In this case, none of these methods will alone prove sufficient to remedy the problems

194. Griffith, supra note 164 , at 453 .

195. Offer of Proof, United States v. Kenny Intemational, supra note 129, at 649-50. The court gave the following description:

Kenny [an American national] and Kenny Intemational [an American corporation] control Cook Islands Development Co., Ltd., a Cook Islands corporation, which does business in

Rarotonga in the Cook Islands .... .

Beginning in December 1965, . . . Kenny obtained the exclusive rights to the promotion, distribution and sale of Cook Islands postage stamps outside the Cook Islands. . . .

. . . Kenny and Kenny International could only be assured of renewal of the stanp distribution agreenent by the continuation of the Cook Island Party's control of the Legislative Assembly and the retention of Sir Albert Henry as Prenier. Anticipating that the election would be closely contested, Sir Albert Henry and his fellow party officials determined that to guarantee their party's continued control in the Legislative Assenibly it would be necessary to transport by air from New Zealand . . . Cook Islands Party supporters to vote for them in the forthcoming election.

On January 23, 1978, ... . a personal representative of Sir Albert Henry and the Cook Islands Party solicited the financial assistance of Kenny and Kenny International . . . . It was requested of Kenny and Kenny International that they subsidize the air transportation costs of the Cook Islands Party supporters. Such a voter subsidy was illegal under Cook Islands law. Kenny, on behalf of Kenny International, ... agreed . . . .

-...

In the general election held in the Cook Islands in March 1978 the Cook Islands Party, as a direct result of the votes cast by its supporters whose travel was paid for by Kenny International, won a majority of seats in the Legislative Assembly and Sir Albert Henry remained in office as Premier. However, in July 1978, . . . the Honorable Chief Justice Donne of the High Court of the Cook Islands disallowed the votes of the Cook Islands Party supporters whose travel had becn subsidized as "unlawful votes tainted by bribery." As a consequence, the Cook Islands Party lost its control of the Legislative Assembly to the opposition party and Sir Albert Henry was renoved from office.

Id. Kenny and Kenny International eventually pleaded guilty to violations of the FCPA. Notice of Plea Agreement and Agreement, United States v. Kenny Int'l Corp., (D.D.C. 1979), reprinted in 2 Foreign Comupt Pracs. Act Rep. (Business Laws, Inc.) 651, 651 (Dec. 31, 1982). 
of the FCPA. The agencies, for the reasons explained above, have failed to enforce the laws or produce sufficient guidelines for adequate adherence. ${ }^{196}$ Without enforcement, the courts have been unable to impose sanctions or reinedy vague terms in the Act. Congress amended the Act in 1988, but could not solve the FCPA's thormest problems. Finally, private citizens have been unable to remedy the situation because they have no standing to bring actions under the FCPA. ${ }^{197}$

\section{III}

\section{Solution: Create a Restricted Private Right of Action}

As it exists today, the Foreign Corrupt Practices Act is flawed in several ways. It sets relatively demanding standards for U.S. firms, but does not define the parameters of those standards. It has attempted to infuse a moral ideal into American business transactions, but has not been supported nor has it been enforced to a degree that would ensure compliance by U.S. firms or induce emulation by other nations. It serves vital long- and shortterm moral, geopolitical, and economic goals, and yet is seen by many as something to be avoided rather than accepted. Nevertheless, as explained above, the Act has several benefits that support its revitalization.

As a result, there is need once again to amend the FCPA. The suggestion detailed below is not, im any way, intended to be the only solution to the problems of the FCPA. It does, however, utilize the most efficient means to achieve the greatest benefits offered by the FCPA.

\section{A. The Proposed Amendment}

The FCPA should be amended to allow a restricted private right of action. ${ }^{198}$ Specifically, the following should be added to the current law:

(1) Any U.S. business, or foreign-owned subsidiary incorporated under U.S. law, which shall be injured by anything forbidden in the prohibited foreigu trade practices provisions of this Act, shall recover threefold the amount of any damages sustained, and the cost of the suit, including a reasonable attorney's fee.

196. See supra Section II.A.

197. Lamb v. Phillip Morris, Inc., 915 F.2d 1024, 1029 (6th Cir. 1990), cert. denied, 498 U.S. 1086 (1991).

198. The courts have consistently held that no implied private right of action is available under the FCPA. See, e.g., id. at 1029; Citicorp Int'l Trading Co. v. Western Oil \& Ref. Co., 771 F. Supp. 600, 606-07 (S.D.N.Y. 1991); Shields ex rel. Sundstrand Corp. v. Erickson, 710 F. Supp. 686, 688 (N.D. Ill. 1989); Lewis ex rel. National Semiconductor Corp. v. Sporck, 612 F. Supp. 1316, 1328-34 (N.D. Cal. 1985). Various commentators bave argued about the correctness of the courts' interpretations. Compare, e.g., Raymond J. Dowd, Note, Civil RICO Misread: The Judicial Repeal of the 1988 Amendments to the Foreign Corrupt Practices Act, I4 FordHAM INT'L L.J. 946, 947-57 (1990-91) (arguing that no implied private right of action exists under the FCPA) with Brett Witter, Note, Lamb v. Phillip Morris, Inc., 915 F.2d 1024 (6th Cir. 1990): The Sixth Circuit Gets Sheepish on Foreign Corrupt Practices Act Enforcement, 5 TransNat'L LAw. 533, 548-60 (1992) (arguing that the Sixth Circuit was incorrect in determining that no implied private right of action exists for the FCPA). 
A U.S. business, or foreign-owned subsidiary incorporated under U.S. law, shall be deemed "injured" under this provision if:

(a) the business competed for, but was not awarded, a contract in a foreign nation; and

(b) another U.S. business, or foreign owned subsidiary incorporated under U.S. law, did receive that contract; and

(c) that second busmess bribed, in violation of the foreign trade practices provisions of this Act, an official of that foreign nation in pursuit of that contract.

(2) The President of the United States can confer standing to bring suit on foreign businesses whose national government has enacted legislation comparable to this Act.

This proposed amendment is neither urique nor revolutionary. Congress generally has the authority to grant standing to private citizens. ${ }^{199}$ In this case, the private right of action is available to a restricted group of potential plaintiffs. Standing under the Act will be limited to those American businesses and foreign-owned subsidiaries incorporated under U.S. law ${ }^{200}$ that believe a competing American business (or foreign-owned subsidary incorporated under U.S. law) is engaged in the bribing of foreign officials. As such, it does not confer standing on either nonbusinesses or foreign-incorporated entities.

The private right of action is limited to American businesses to allow fair competition. United States businesses should not fear being sued by, for example, a Japanese corporation for violating the FCPA when the Japanese corporation, unhindered by similar legislation, could not be conversely sued. As certain nations adopt legislation which is similar to the FCPA, the President is allowed to confer standing on businesses from those countries.

The proposal is restricted to competing businesses in order to promote flexibility in enforcement. Such a restriction allows the private right of action to keep pace with changing times and economic realities. Thus, in

199. Congress may grant an express right of action to persons who otherwise would be barred by prudential standing rules. ... [So long as the plaintiff alleges a distinct and palpable injury to him or herself], persons to whom Congress has granted a right of action, either expressly or by clear implication, inay have standing to seek relief . . . .

Warth v. Seldin, 422 U.S. 490, 501 (1975); see also Linda R.S. v. Richard D., 410 U.S. 614, 617 n.3 (1973) ("Congress may enact statutes creating legal rights, the invasion of which creates standing, even though no injury would exist without the statute."); Trafficante v. Metropolitan Life Ins. Co., 409 U.S. 205, 209 (1972) (Congress may explicitly grant standing as broadly as Article III permits). See generally William A. Fletcher, The Structure of Standing, 98 Y ALE L.J. 221 (1988) (describing the courts' historical approach to standing and suggesting a more refined and simplistic measurement).

200. This added langnage is intended to allow standing for foreign-owned subsidiaries that must adhere to U.S. law, and thus must contend with the FCPA's provisions whenever attempting to engage in transactions abroad. For example, Honda of America currently must abide by the FCPA if it sells abroad. Honda of America, having been incorporated under U.S. law, would then be allowed to bring suit under this private right of action against Ford, for example, if Ford were to bribe foreign officers (and vice versa). 
nations where bribery is rare, U.S. businesses have a large economic interest in bringing suit against other U.S. businesses that bribe foreign officials. $^{201}$ It can be expected that, in such nations, U.S. coinpanies will utilize the private right of action both often and with fervor. Conversely, in nations where bribery is widespread, restricting suits to competing U.S. businesses allows a marked decrease in private enforcement; presumably, all U.S. businesses engaged in activities in these nations will feel compelled to bribe and, thus, will be unlikely to sue each other for engaging in such bribery. If such bribery becomes too extreme, or if the foreign nation begins to alter its policies, a U.S. business begins to have incentives to sue. Of course, if such incentives do not prove sufficient, the DOJ still has authority to bring action.

This flexibihity is one of the greatest assets of the proposed private right of action. Yet it is based on the fact that the private right of action is restricted to businesses. Stockholders, and even employees, may be vulnerable to business violations of the FCPA. ${ }^{202}$ However, they do not have the same long-term interests as the company. ${ }^{203}$ Thus, granting these individuals standing would greatly reduce the flexibility of the private right of action described in the preceding paragraph. For example, assume that Nation $A$ is notorious for bribery. Assume also that companies $X$ and $Y$ both compete for a contract with Nation $A$ and company $X$ gets the contract because it bribed Nation $A$ 's Prime Minister. Company $Y$, in deciding whether to bring suit under the FCPA, would take into consideration the economic chmate of Nation $A$-i.e., is the loss of this contract worth the likehhood of being sued in the future when we, Company $Y$, will find it necessary to bribe the Prime Minister of Nation $A$ to get a contract? A stockholder of Company $Y$, however, would not weigh these factors.

201. In the proposed amendment, only competing businesses can be "injured." Noncompcting busmesses may also be harmed by violations of the FCPA. For example, bribes by one U.S. company in a foreign nation might create the impression that U.S. corporations always bribe. This may harm futurc U.S. companies attempting to acquire contracts in that nation. However, such "injury" would be difficult to prove, as would damages. Thus, the proposed restriction is made to establish a more bright line rule of what constitutes injury and to aid courts in narrowly defiming which partics can bring suits.

202. Stockholders can be adversely affected financially if a business in which they have invested suffers a loss as a result of bribery. See Newman \& Burrows, supra note 57, at 3. For example, suppose that U.S. corporation $X$ bribes a foreign official and wins a contract for which U.S. corporation $Y$ also competed. Shareholders of $X$ could be harmed if the information is leaked, $X$ is prosecuted, or the bribe was unnecessary. Shareholders in corporation $Y$ could be harmed by the lost business. Employces can also suffer damages when their company bribes foreign officials. The employees can be in danger of losing their jobs for either refusing to participate in or cover up illegal bribes. Id. In recognition of this possibility, some courts have held that an employee who exposes her employer's bribe or refuses to give a bribe is already protected by the courts if she is wrongfully discharged. See Williams v. Hall, 683 F. Supp. 639, 643 (E.D. Ky. 1988); Thompson v. St. Regis Paper Co., 685 P.2d 1081, $1089-90$ (Wash. 1984).

203. The stockholder, especially in a publicly traded corporation, can and often will dispose of the stock after a short period of time. An employee, meanwhile, is often concemed with only limited aspects of the company and any contract that the company makes. Both stockholders and employces, then, may become obsessed with a particular transaction and thus miss the larger picture. 
Noting the immediate short-term loss, it would likely be in her interest to bring suit against Company $X$, regardless of the long-term implications to Company $Y$. This then negates all flexibility allowed under the proposed private right of action.

Beyond harming flexibility, individuals are denied the right to bring suit under the proposal for other reasons. In many instances, it would be difficult for such individuals to describe how they have been distinctly harmed by the bribe. They would also have problems acquiring sufficient evidence to bring suit. ${ }^{204}$ Furthermore, allowing individuals to bring suit would likely greatly increase the number of cases brought to trial. Not only would this increase the possibility of nuisance suits, but also lead to increased clogging of the court system. Finally, restricting the right of action to businesses and not providing standing for shareholders serves public policy by insuring that enforcement of FCPA violations will not be greater for publicly held corporations than for privately held ones.

Individuals, however, would not be without recourse to enforce compliance with the provisions of the FCPA. Harmed individuals can induce competitors of the firm to bring suit. Individuals can also exercise influence through shareholder's meetings or the media. ${ }^{205}$ Furthennore, individuals may be able to bring other types of actions, mcluding $\mathrm{RICO},{ }^{206}$ antitrust, ${ }^{207}$ or wrongful discharge. ${ }^{208}$ Finally, individuals can always provide inforination to the DOJ or SEC and allow these agencies to bring an enforcement action.

A potential objection to the proposal's restriction of standing to businesses is that it may encourage a conspiracy of silence annong U.S. competitors. However, it is unlikely that competitors would be able to maintain such a huge conspiracy. On the idealistic side, the competitive spirit of American industry would serve to limit the potential of any such conspiracy. On the realistic side, the busmesses that lose the contract would probably bring suit, regardless of the conspiracy. In any case, such conspiracies are illegal under U.S. law. ${ }^{209}$

204. The particular ability of businesses to acquire evidence to bring suit is discussed at infra text accompanying notes $242-43$.

205. One of the major incentives for compliance with the Act is the negative publicity that accompanies violators. As one observer notes, "[in]ost managers would agree that the strengths of consumers, public opinion and the inedia are far inore serious problems than the law." When in Rome, MNCs Don't Always Do as the Romans, supra note 167 (statement of Professor James Kuhn, Director of Columbia University's Researclı Center for Business Ethics); see also supra note 62 (discussing desire of firms to avoid bad publicity).

206. See Dowd, supra note 198 , at $965-70$ (providing numerous examples of RICO claims by individuals under FCPA allegations).

207. Id. at 965.

208. See Williams, 683 F. Supp. at 643; Thompson, 685 P.2d at 1089-90; supra note 202.

209. Conspiracies are anticompetitive, and as sucl would likely violate antitrust laws and be actionable under the Clayton Act. 15 U.S.C. $\$ 15$ (1988). 


\section{B. Benefits of the Proposal}

The proposed restricted private right of action would greatly improve the currently beleaguered FCPA. Not only would this restricted private right of action solve many of the specific problems that currently plague the Act, but it would also help address some of the more general, underlying difficulties created by this legislation. Although creation of such a private right of action could cause problems, fortunately, antitrust law can serve as a guide for solving some of the more tangled dilemmas posed by the creation of a private right of action for the FCPA.

\section{A Restricted Private Right of Action Solves Many of the Current Problems of the Act}

The purpose behind this private right of action provision is to strengthen the FCPA's key problems - vagueness and mimimal enforcement-without extensive and detailed amendments by Congress. Further congressional definitions of the Act's provisions are unlikely to prove helpful, given the vagueness of the entire concept of bribery, as well as the often fast-paced changes in the international world and international business. In addition, Congress has already demonstrated its inabilities to deal with the specific problems of the Act. Though difficulties with the Act were apparent from its very inception, ${ }^{210}$ it took Congress eleven years to amend the FCPA. As noted earlier, despite the long time-delay, Congress failed to clarify the troubled portions of the FCPA. ${ }^{211}$ As Congress appears unable to contend with the needs of the FCPA, a more flexible forum needs to be employed. Since both the DOJ and the SEC seem unable or unwilling to enforce and interpret the FCPA, ${ }^{212}$ the impetus must come from elsewhere.

This proposal places the impetus on the injured parties, the U.S. businesses unable to compete effectively due to unfair practices by other U.S. businesses. These parties are directly affected by the unfair practices of their competitors and have the most to gain by enforcing the provisions of this Act. This incentive will bring more FCPA suits to the courts and, as such, will make compliance with the Act a greater focus of U.S. businesses.

A private right of action can also aid in achieving the economic and moral goals of the FCPA. As stated above, many nations have recently imitiated programs to combat corruption. ${ }^{213}$ Greater enforcement, coupled with increased agency and court action, could provide the impetus for these nations to enact legislation along the lines of the FCPA, or at least encourage the United Nations and the OECD to adopt related codes of con-

210. See supra text accompanying notes 28-30.

211. See supra Part II.B.

212. See supra notes $46-65$ and accompanying text.

213. See supra notes $178-85$ and accompanying text. 
duct. While initially creating short-term drawbacks, ${ }^{214}$ all of these events will help increase the long-term benefits of the FCPA for U.S. businesses.

Greater enforcenent will also solve some of the vagueness problems of the FCPA. Either in conjunction with, or in lieu of, agency guidance, the increased enforcennent will push U.S. courts to establish precedent for the FCPA's provisions. In doing so, the court systen merely fulfills one of its inajor functions: providing specific guidance regarding vague standards. The courts have already provided guidance on some minor concepts regarding the FCPA;215 increased enforcement would allow even greater use of the courts' abilities.

In addition to court guidance, a private right of action will induce more firms to utilize the DOJ review procedure to help determine whether they are in compliance with the Act's provisions. Firms will also place pressure on the DOJ and SEC to establisl and inpleinent more specific guidelines for FCPA compliance. With firms currently shying away from the Act, and using the review procedure as little as possible, the DOJ and SEC have had little pressure to create such guidehnes. The agencies have also had little incentive to conduct surveys and investigations to determine the pervasiveness of bribery. This proposal for a restricted private right of action will propel these agencies in the right direction.

\section{Precedent in Antitrust Law Provides Guidance}

When an amendment to existing legislation is proposed, it is invariably difficult to ascertain exactly what inpact it will have on the real world. However, a clue to the effect of the proposed amendment may be found in the Clayton Antitrust Act, ${ }^{216}$ which has had a long-standing private right of action. The purpose of the Clayton Act is to protect Aunerican businesses and consumers from the unfair trade practices created by a monopoly. As such, it bears numerous similarities to the FCPA. Both Acts refiect a Congressional desire to protect economic freedom and free markets. ${ }^{217}$ Both inpose value judgment restrictions on U.S. businesses operating abroad. $^{218}$ Also, both have practical economic benefits despite apparent short-term negative effects on American competitiveness. Finally, both are

214. The short-term drawbacks most prominently include increased litigation costs. These costs will, however, decrease as more firms change their behavior, resulting in fewer U.S. firms violating the FCPA.

215. See supra notes $69-73$ and accompanying text.

216. 15 U.S.C. $\S 15$.

217. For a discussion of the FCPA's ability to protect free markets, see supra notes $186-89$ and accompanying text. For a discussion of how the Clayton Act, and its predecessor the Sherman Act, protect free trade, see United States v. Topco Assocs., Inc., 405 U.S. 596, 610 (1972) ("Antitrust laws in general, and the Sherman Act in particular, are the Magna Carta of free enterprise. They are as important to the preservation of economic freedom and our free-enterprise system as the Bill of Rights is to the protection of our fundamental personal freedoms.").

218. Of course, the Clayton Act applies to domestic actions as well, unlike the FCPA which applies exclusively to foreign bribery. 
predominantly American ideas, neither having an equal of comparable strength in any foreign nation. ${ }^{219}$ Thus, both the Clayton Act and the FCPA are fairly unique American tools designed to restrict American business efforts abroad. 220

To aid the Clayton Act in effectuating its goals, Congress created a private right of action. Section 4 of the Clayton Act provides:

[A]ny person who shall be injured in his business or property by reason of anything forbidden in the antitrust laws may sue therefor in any district court of the United States in the district in which the defendant resides or is found or has an agent, without respect to the amount in controversy, and shall recover threefold the damages by him sustained, and the cost of suit, including a reasonable attorney's fee. ${ }^{221}$

This private right of action was established "not merely to provide private relief, but was to serve as well the high purpose of enforcing the antitrust laws." 222 Specifically, Section 4 "was designed to supply [an] ancillary force of private investigators to supplement the Department of Justice in law enforcement." 223 Even more critically, the private right of action of the Clayton Act was created to "aid[] in achieving the broad social objectives of the statute"224 by "insuring that the private action will be an ever-present threat to deter anyone contemplating business behavior

219. While the FCPA is uniquely American, antitrust law has been adopted in Europe. See Nick Gardner, A Guide to United Kingdom and European Community Compettion Policy 22-24 (1990). However, the European approach does not emphasize monopolization, which is the key component of American antitrust law. Furthermore, the European approach is more discretionary, more narrow, and less complete than the American model. Id. at 18-24. Finally, antitrust laws only emerged in Europe after World War II. Id. at 182. Such laws have existed in the United States for over 100 years. See infra note 228. Thus, antitrust law was adopted by European nations only after it had been an exclusively American concept for a period of time. One can hope the FCPA will induce the same reaction.

220. There are, of course, important differences between the two Acts. See George C. Greanias \& Duane Windsor, The Foreign Corrupt Practices Act 143-49 (1982) (providing extensive details about how the FCPA differs from antitrust legislation). The Clayton Act applies to domestic, as well as foreign, transactions. The Clayton Act is probably easier to enforce, given that it normally involves only American actors, while the FCPA, by definition, concems a fureign official as wcll as American corporations. The Clayton Act is also probably less intrusive on American foreign intercsts in that the polieies and officials of foreign nations are usually not implicated.

Nonetheless, the comparison here is not meant to be exact. It merely demonstrates that certain basic concepts are inherent im both acts. The differences articulated above do not detraet from the fact that a private right of action in the Clayton Act has helped enforcement of that Act's provisions, clarified numerous vague principles, and proven successful for over 100 years. See infra note 228. The FCPA can act in a similar way by providing a private right of action. The Clayton Act, then, provides an example where a private right of action worked to serve important policy interests.

221. 15 U.S.C. $\S 15(\mathrm{a})$.

222. Zemith Radio Corp. v. Hazeltine Research Inc., 395 U.S. 100, 130-31 (1969).

223. In re The Pittsburgh \& Lake Erie R.R. See. \& Antitust Litig., 387 F. Supp. 906, 908 (1974).

224. Id. 
in violation of the antitrust laws."225 However, the private right of action is not rigid, but rather is "flexible and capable of nice 'adjustment and reconciliation between the public interest and private needs as well as between competing private claims." "226 As such, Section 4 is remarkably similar to the proposed private right of action for the FCPA, which was also created to bolster enforcement and help achieve the broad social objectives of the statute, while remaining sufficiently flexible to allow public interest to be balanced with private needs. ${ }^{227}$

The Clayton Act can thus be extremely helpful in understanding the proposed private right of action for the FCPA. The one hundred year existence of this private right of action ${ }^{228}$ has given the courts and other branches of the government a considerable period in which to analyze and address the consequences of such a right of action. Given the parallels between the FCPA and the Clayton Act, the decisions of the courts concerning the latter can now easily be applied to the former. ${ }^{229}$ In the end, then, just as the FCPA has been suggested as a model for other proposed legislation, ${ }^{230}$ so too can the Clayton Act be used to guide the FCPA in adopting a private right of action.

225. Id. at 910 (quoting Perma Life Mufflers, Inc. v. International Parts Corp., 392 U.S. 134, 139 (1968)).

226. Zenith Radio Corp., 395 U.S. at 131 (quoting Hecht Co. v. Bowles, 321 U.S. 321, 329-30 (1944)).

227. See supra notes $212-15$ and accompanying text. There are, of course, some differences between the private rights of action. Specifically, the proposed FCPA provision is more restrictive in its standing requirements (restricting standing to competing U.S. busmesses) and also has the goal of helping interpret the vagueness of the FCPA's provisions.

228. Section 4 of the Clayton Act is based on $\S 7$ of the Sherman Act, which was enacted in 1890 . Associated Gen. Contractors v. California State Council of Carpenters, 459 U.S. 519, 530 (1983).

229. In just the last few years, in fact, the Supreme Court has taken the opportunity to analyze numerous problems associated with the Clayton Act's private right of action. See Atlantic Richfield Co. v. USA Petroleum Co., 495 U.S. 328, 334-45 (1990); Cargill, Inc. v. Monfort, Inc., 479 U.S. 104, 10913 (1986); Associated Gen. Contractors, 459 U.S. at 529-35. While detailed analysis of the decisions of the courts concerning this private right of action over the last 100 years falls beyond the scope of this Comment, the fact that the Supreme Court has engaged in such extensive analysis benefits the FCPA proposal. For a good, concise discussion of relevant decisions, see Philip Geller, Annotation, Standing to Sue, Under \$ 4 of the Clayton Act (15 U.S.C.S. § 15) and Predecessor Statute, to Recover Treble Damages for Antitrust Violation-Supreme Court Cases, 73 L. Ed. 2 d 1427 (1981 \& 1992 Supp.).

230. The FCPA has served as a model for proposed environmental legislation. See Alan Neff, Not in Their Backyards, Either: A Proposal for a Foreign Environmental Practices Act, 17 EcoLocy L.Q. 477,492 (1990) (proposing that the FCPA serve as a guide to prohibit extraterritorial environmental practices by U.S. corporations abroad); Barbara Scramstad, Comment, Transboundary Movement of Hazardous Waste from the United States to Mexico, 4 TRANSNAT'L LAW. 253, 288-89 (1991) (same). The Act has also been a guide for proposed anti-discrimination laws concerning the actions of U.S. corporations abroad. See Debra A. Stegura, Note, The Biases of Customers in a Host Country as a Bona Fide Occupational Qualification: Fernandez v. Wynn Oil Co., 57 S. CAL. L. Rev. 335, 358 (1984) (urging that legislation similar to the FCPA be enacted in order to prohibit discrimimatory hiring practices by U.S. firms abroad). 


\section{Potential Problems with the Proposal}

Despite the numerous advantages of a restricted private right of action, there are a few possible complications that demand attention. What follows is an attempt to anticipate potential problems arising from a private right of action.

\section{Possible Redundancies as Litigants Can Already Prosecute Bribery Under RICO}

Althougl private litigants are currently barred from bringing suits under the FCPA, they are not barred from bringing suits under the Racketeer Influenced and Corrupt Organizations Act (RICO). In Environmental Tectonics Corp., International v. W.S. Kirkpatrick \& Co., ${ }^{231}$ the Third Circuit allowed foreign bribes that violated the FCPA to serve as a predicate act for a civil RICO action. ${ }^{232}$

However, this dual coverage does not eliminate the need for the FCPA to liave its own private riglt of action. First, other courts might bar private suits of the type in Environmental Tectonics, since Congress expressed no intent to allow private rights of action under the FCPA. ${ }^{233}$ None of the courts reviewing the Environmental Tectonics claim explicitly addressed the intent of Congress to allow a private right of action under the FCPA. ${ }^{234}$ However, at least one commentator has noted that such a failure to address the issue was erroneous: the fact that the FCPA does not have an express or implied private right of action should bar the use of the FCPA as a predicate act for private rights of action brought under RICO. ${ }^{235}$

Second, even if courts allow a plaintiff to bring a private action througlı such a circuitous route, RICO's demanding requirements will exclude many claims. Numerous restrictions apply to plaintiffs alleging RICO violations. ${ }^{236}$ The most significant restriction on RICO prosecutions

231. 847 F.2d 1052 (3rd Cir. 1988), aff'd on other grounds, 493 U.S. 400 (1990).

232. Id. at 1063-64. In Environmental Tectonics, the court allowed the private suit, but focused its opinion on whether the suit under RICO violated the act of state doctrine. Without discussing whether the FCPA should allow private suits either directly or indirectly (as a predicate act for RICO), the Supreme Court affirmed the Third Circuit decision that the act of state doctrine did not bar such RICO claims. W.S. Kirkpatrick \& Co. v. Environmental Tectonics Corp., Int'1, 493 U.S. 400, 409-10 (1990), In another case, United States v. Young \& Rubicam, Inc., 741 F. Supp. 334,339 (D. Conn. 1990), the court allowed the United States government (not private litigants) to use the FCPA as a predicate act for a criminal prosecution under the Travel Act, which in turn was deemed a predicate act of RICO.

233. Detailed and very persuasive arguments that Congress did not intend the FCPA to include an: implied private right of action can be found in Lamb v. Phillip Morris, Inc., 915 F.2d 1024, 1027-30 (6th Cir. 1990), cert. denied, 498 U.S. 1086 (1991), and Lewis ex rel. National Semiconductor Corp، v. Sporck, 612 F. Supp. 1316, 1328-34 (N.D. Cal. 1985).

234. See W.S. Kirkpatrick \& Co., 493 U.S. at 402; Environmental Tectonics Corp., 847 F.2d at 1056; Environmental Tectonics Corp., Int'l v. W.S. Kirkpatrick \& Co., 659 F. Supp. 1381, 1386-87 (D.N.J. 1987).

235. See Dowd, supra note 198 , at $946-47$.

236. A detailed analysis of RICO and its components is beyond the scope of this Comment. For further reading, see Gregory P. Joseph, Civil RICO: A Definitive Guide (1992). 
is the requirement that there exist a "pattern of racketeering activity."237 The " "pattern of racketeering activity' requires at least two acts of racketeering activity ... the last of which occurred within ten years . . . after the commission of a prior act of racketeering activity."238 However, "while two acts are necessary, they may not be sufficient. ... [I]n common parlance two of anything do not generally form a "pattern." "239 Although the Supreme Court has twice attempted to determine what defimitively constitutes a pattern, "the concept remains elusive," and the circuit courts are split. $^{240}$

Using the FCPA as a predicate act for RICO, then, might be extremely difficult. Different courts may come to different decisions on the saine facts. In addition, the requirement that a pattern of racketeering exists suggests that a one-bribe exchange may not suffice. Thus, some plaintiffs may not be able to bring suit. Furthermore, using the FCPA as a predicate act for RICO requires a plaintiff to fulfill the requirements, and bear the proof, of two acts, and not just one. An independent private right of action under the FCPA itself avoids these problems.

\section{Few Businesses Are Likely to Bring Suit}

Despite the streamlined approach offered by a private right of action, the possibility exists that few U.S. busmesses would sue competitors for FCPA violations. Not only might such whistleblowing endanger the firm's standing in the business community, but it might also prompt retaliatory suits. Perhaps even more importantly, a firm might be reluctant to bring a suit for fear of offending a nation that could supply future contract orders.

These concerns, however, are probably exaggerated. The fear of being an antitrust whistleblower has not prevented a healthy streain of private litigation in that field. ${ }^{241}$ Moreover, since an FCPA plaintiff can profit from the favorable public opinion linked to exposing corruption, there would be a strong additional incentive for an aggrieved firm to assert its riglits. Last, the fact that successful litigants are entitled to remedies equal to threefold damages will likely serve as a further inducement to bring suit.

It could be argued, however, that even if businesses have the desire to bring suit, they would have difficulty acquiring sufficient evidence to put forward a legitimate claim. This has been a key difficulty for the DOJ and

237. 18 U.S.C. $§ 1961(5)$ (1988); see also Agency Holding Corp. v. Malley-Duff \& Assocs., 483 U.S. 143, 154 (1987) ("[T]he heart of any RICO complaint is the allegation of a pattern of racketeering."); JoSEPH, supra note 236, at 82-83.

238. 18 U.S.C. $\S 1961(5)$.

239. Sedima, S.P.R.L. v. Imrex Co., 473 U.S. 479,496 n.14 (1985).

240. JosEPH, supra note 236, at 82-95. In addition, Newman and Burrows note that there is also a split between federal courts of appeals over whether the harm alleged in the RICO schemes must have been direetly caused by specified predicate acts. Newman \& Burrows, supra note 57, at 29 \& nn.36-38.

241. See supra notes $228-30$ and accompanying text. 
SEC. ${ }^{242}$ American firms, however, would have several advantages over these government agencies in acquiring evidence. American businesses have connections that the government agencies do not. American businesses probably have a better knowledge of the country and how it works than either the SEC or the DOJ. Due to the stakes involved, the American businesses will have greater incentive to file suits, and may subsequently utilize greater staff and larger funds im private actions than the government would employ in a criminal prosecution. ${ }^{243}$ Thus, it is unlikely that American businesses would lack either the incentives or the abilities to bring forth successful claims.

\section{Too Many Firms Would Bring Suit}

Alternatively, the creation of a private right of action could create an overabundance of litigation, which would prove too costly to American firms. Included in the potential deluge would be nuisance claims as well as claims used to squash competition.

However, such an onslaught of litigation is unlikely. Despite the advantages firms may have over the government in finding evidence of bribery abroad, it is nevertheless a difficult endeavor, ${ }^{244}$ requiring enough determination and resolve to discourage nuisance suits. It is thus unlikely that a firm would employ the extraordinary time and effort to bring such a claim unless it actually believed that improprieties had occurred. In any case, there are much easier ways to bring a nuisance claim than to prove

242. See supra notes 56-57 and accompanying text; see also Longobardi, supra note 12, at 477 (mentioning discovery, the Sixth Amendment, and other problems).

243. Individuals may also be aided by the Hague Convention on the Taking of Evidence Abroad in Civil or Commercial Matters, opened for signature Mar. 18, 1970, 23 U.S.T. 2555, 847 U.N.T.S. 231. The Convention aids the citizens of contracting states in obtaining evidence for domestic civil and commercial matters. Since much of current FCPA enforcement is handled by the DOJ in the criminal context, see supra text accompanying note 27 , the advantages of this Convention are often unavailablc. Private citizens initiating civil suits under the FCPA, however, would be able to utilize the Convention's benefits.

Unfortunately, the applicability of this Convention in U.S. law is unclear. In Societe Nationale Industrielle Aérospatiale v. United States Dist. Court, 482 U.S. 522 (1987), the Supreme Court held that the Convention was not the exclusive means for discovery, id. at 539-40, and created an ad hoc balancing test to determine when the Convention should be utilized, id. at 544 . The stringent requirenients contained in this test place a considerable burden on persons seeking to utilize the Convention. Joseph P. Griffin \& Mark N. Bravin, Beyond Aerospatiale: A Commentary on Foreign Discovery Provisions of the Restatement (Third) and the Proposed Amendments to the Federal Rules of Civil Procedure, 25 INT'L LAw. 331, 336 (1991). This has led U.S. courts to allow the use of the discovery rules contained in the Federal Rules of Civil Procedure. Id. at 340 . While these rules are broader than the provisions contained in the Convention, foreign governments have grown fearful that their nationals are vulnerable to what is perceived as the excessive reach of American discovery. Id. As a result, numerous foreign nations have enacted or strengthened blocking provisions that protect thcir nationals from such discovery. Id. For a discussion of the effect that the Convention has had on U.S. enforcement of the securities laws, see Daniel L. Goelzer \& Anne Sullivan, Obtaining Evidence for the Intermational Enforcement of the United States Securities Laws, 16 BROOK. J. INT'L L. 145, 159-63 (1990).

244. See supra notes $56-57,242-43$, and accompanying text. 
foreign bribery. Of course, a true nuisance claim would be subject to Rule 11 sanctions, as well as potential retaliatory suits by other firms.

While a vast amount of litigation is unlikely, there would almost certainly be some increase in litigation. Far from being detrimental, an increase in litigation would help solve many of the problems of the FCPA. As explained earlier, ${ }^{245}$ it would clearly aid in increasing enforcement and dimimishing vagueness problems, whicl in turn would help promote the long-term benefits of the FCPA.

\section{Other Solutions Would Be More Efficient}

It can be argued that other solutions to the problem would be more direct and more efficient. The most notable of these suggestions would be to urge other nations to enact legislation similar to the FCPA or to urge the establishment of clearer guidelines by the SEC and DOJ. These are legitimate suggestions and, to the extent possible, should be pursued. ${ }^{246}$

However, there are distinct problems with both of these suggested tactics. Urged by the United States, the global community has already considered, and for the time being discarded, the notion of enacting legislation similar to the FCPA. While there is some indication that certain nations may be induced to consider antibribery provisions, ${ }^{247}$ the international community as a whole has been reluctant. In recent years, United Nations committees have twice considered prohibitions on bribery of foreign officials. ${ }^{248}$ However, neither effort met with success and it appears that the United Nations has stepped away from consideration of these issues in the upcoming sessions. ${ }^{249}$ The OECD has also been approached regarding

245. See supra text accompanying notes 212-15.

246. As noted before, a private right of action under the FCPA would, in fact, promote both these options by inducing corporations to put pressure on the agencies to create better guidelines and on the President to urge reforms abroad. See supra Part III.B.1.

247. In France, for example, a French advisory panel on corruption called on the French government to deter French firms from paying bribes to win foreign contracts. French Panel Advises Ban on Paying Bribes, J. ON Com., Jan. 13, 1993, at A5. In Israel, a survey of the 140 largest Israeli corporations found that more than two-thirds of the corporations refuse to conduct business according to locally accepted "unethical practices," and $70 \%$ of those surveyed would support the creation of FCPAlike legislation. See Bainerman, supra note 147, at A7. A representative to the United Nations from the Intemational Organization of Consumers Unions suggested that American urging could induce other nations to accept codes that would prohibit bribery of foreign officials. Esther Peterson, Ethics Shouldn't Stop at the Water's Edge, Christian ScI. Monitor, Aug. 22, 1989, at 19.

248. See Peterson, supra note 247, at 19; see also U.N. Centre on Transnat'L Corps., Proposed Text of the Draft Code of Conduct on Transnational Corporations, in THE New CODE ENvIRONMENT annex at 37, U.N. Doc. ST/CTC/Ser.A/16, U.N. Sales No. E.90.II.A.7 (1990) (proposed model code including antibribery provisions); U.N. Commission on Transnational Corporations, Report on the Seventeenth Session, U.N. ESCOR, 1991 Sess., Supp. No. 10, at 10, U.N. Doc. E/1991/31-E/C.10/1991/ 17 (1991) (requesting action by the U.N. Secretary General to expedite passage of the Draft Code).

249. The Secretary General's attempts to acquire comment on the proposed Code met with little interest. See Report of the Economic and Social Council: Code of Conduct on Transnational Corporations, U.N. GAOR, 46th Sess., Agenda Item 12, app. at 4-5, U.N. Doc. A/46/558 (1991). 
the creation of greater FCPA support world-wide. ${ }^{250}$ However, its attempts met with a similar lack of notable success. ${ }^{251}$

The United States has been the sole possessor of legislation like the FCPA for sixteen years. Unless the United States can dentonstrate the exceptional value of the FCPA, other nations appear unlikely to erect their own corrupt practices acts. The proposed private right of action attempts to provide numerous incentives to these nations. By cleaning up the Act's vague provisions, the private right of action will make the FCPA a model guide that other countries can easily adopt. By increasing enforcement, the private right of action will prompt American firms to lobby the U.S. government to create bilateral and multi-lateral treaties on corruption and will illustrate to other countries that bribery can be eradicated. By expediting the realization of the FCPA's economic, moral, technological, and geopolitical benefits, as well as inducing lesser-developed nations to eliminate corruption, a private right of action will demonstrate to foreign nations the benefits of antibribery legislation. The private right of action makes these incentives viable and thus provides the necessary impetus for foreign nations to adopt legislation similar to the FCPA.

In addition to urging international adoption of antibribery provisions, the DOJ could aid the FCPA by issuing more concrete guidelines. However, this suggestion has been met with resistance from the DOJ. The DOJ is afraid that if it presents only a few hypothetical transactions as being legal under the FCPA, American corporations will feel unduly obligated to fit their practices into one of those examples. ${ }^{252}$ If, on the other hand, the DOJ attempts to list every possible permutation, companies will have to search through a voluminous list to determine if their fact situation meets one of the hypotheticals. ${ }^{253}$ Given the DOJ's understandable reluctance in this area, it is unlikely that DOJ guidelines will be provided in the future. ${ }^{254}$ However, a private right of action will prompt American industry to apply pressure on the DOJ to clarify ambiguous parts of the Act's provisions.

\section{CONCLUSION}

The FCPA is needed in American society. Along with the desirable moral ideals furthered by the FCPA, the Act advances Anterica's geopolitical and economic interests. Unfortunately, the Act itself contains various defects. Many provisions are too vague to provide guidance, and enforce-

250. Aronoff, supra note 42 , at $820-22$.

251. Id.

252. Longobardi, supra note 12 , at 475.

253. Id.

254. Nonetheless, the DOJ could aid corporations by allowing anonymous inquiries and more visibly publishing the decisions of the review procedure. These approaches, however, would prove less forceful and less effective than the proposed private right of action. 
ment has been too weak to induce either clarification or compliance. These extensive problems demand drastic action: the Act must be amended.

The most efficient, and most effective, means for solving the problems of the FCPA is to create a private right of action restricted to competing U.S. businesses. This will effectuate the congressional goal of balancing the need for antibribery measures with the desire to allow U.S. businesses to remain competitive. It will also serve to increase enforcement which will, in turn, serve to define many of the uncertain terms contained in the Act.

Problems with a restricted private right of action are certain to occur. Some of these have been detailed above and others, undoubtedly, will surface as time passes. Nonetheless, the FCPA is in great need of reform if its goals are ever to be attained. Given the tremendous changes in global politics and the current exigencies of the American economy, a restricted private right of action is the best way to achieve those goals quickly, effectively, and realistically. 
